\title{
BACK TO BASICS: REGULATING HOW CORPORATIONS SPEAK TO THE MARKET
}

\author{
Ian Ayres*
}

N Monday October 19, 1987, the Dow Jones Industrial Average
of New York Stock Exchange Listings dropped 508 points, a
decline of 1nore than twenty-two percent of its value in a single day. Two wecks later, on Monday, Noveinber 2, the United States Supreme Court heard argument in Basic Inc. v. Levinson. ${ }^{1}$ Argumg that stock inarkets efficiently reflect all public information concerning price, former shareholders of Basic claimed that they had sold their shares at an artificially depressed price because inanagenient had derned falsely that the corporation was engaged in inerger negotiations. ${ }^{2}$ Although the shareholders did not know of the corporation's stateinents at the time they sold their shares, and tlierefore could not prove reliance in the traditional sense, they argued they could rely on the integrity of the inarket to reflect such information. In the chaos and continued fall in the stock niarket following Black Monday, it is not surprising that at oral argument the defendant directors described stock inarket efficiency as "a hypothesis tliat inany people have ques-

* Visiting Professor, Yale Law School (Fall 1991). Professor, Stanford Law School (1992- ). B.A., Yale University; J.D., Yale Law School; Ph.D. (Economics), Massachusetts Institute of Technology. John Donohue, Rob Gertner, Ron Gilson, Joe Grundfest, David Haddock, Tonı Jackson, Ed Kitch, Paul Mahoney, Chuck O'Kelley, Mitch Polinsky, Dan Polsby, Roger Schecter, Bob Scott, Ken Scott, Peter Siegehnan, Bill Stuntz and William S.K. Wang provided helpful comments. Bernie Black, in particular, went beyond the call of duty in improving the quality of an early manuscript. The support of Northwestern's Corporate Counsel Center and Virginia's Olin Program in Law and Economics is gratefully acknowledged.

1485 U.S. 224 (1988).

2 Id. at 228. Basic Inc., a publicly traded conipany, made chemical refractories for the steel industry. In Septeinber, 1976, Basic's officers and directors began extended inerger negotiations with representatives of Combustion Engineering, Inc. During 1977 and 1978, Basic made three public statements falsely denying that it was engaged in merger negotiations. On December 20,1978, Basic announced that its board had approved Conbustion's tender offer for all of its outstanding shares. Id. at 226-28. Shareholders who sold Basic shares between the time of the first public statement denying inerger negotiations and the public announceinent of the tender offer brought suit claiming that Basic and its officers and directors had violated Rule $10 \mathrm{~b}-5$. 
tioned in liglit of the events of the last few weeks."3 Notwithstanding the market crash, a plurality of the Supreme Court ultimately accepted the "fraud-on-tlie-inarket" basis for plaintiff standing under Rule 10b-5. ${ }^{4}$

By allowing plaintiffs in class actions to claim a fraud-on-tle-market as a substitute for individualized proof of reliance on manageinent's false statements, the Basic decision has dramatically reinvigorated the use of $10 \mathrm{~b}-5$ actions to attack corporate misrepresentations. This Article addresses two issues at the core of the Basic decision: (1) whetler corporations slould be allowed to lie to the market; and (2) how different notions of stock market efficiency underlie regulation of corporate speech and other aspects of corporate law.

Part I argues that corporations sliould be given the option of lying, but tliat corporations that contemplate lying should be forced to disclose that they do not warrant the truth of their stateinents. Efficient corporate law shonld not only give corporations the opportunity to precommit to honesty, it sliould give thein the opportunity to precommit to silence, as well. When given these clioices, inarket forces will drive virtually all firms to commit to honesty, and at least some will commit to (or establish reputations for) reinaining silent.

Part II distinguishes between two independent dimensions of stock inarket efficiency: A market is "informationally efficient" if certain classes of information are immediately incorporated into a stock's price; a market is "fundamentally efficient" if a stock's price refleets only information relating to the net present value of the corporation's

3 Petitioners' Oral Argument at 17, Basic Inc v. Levinson, 485 U.S. 224 (1988) (No. 86279).

4 Justice Harry Blackmun authored the plurality opinion which Justices William Brennan, Thurgood Marshall and John Paul Stevens joined. Justices Byron White and Sandra Day O'Connor joined the Court's holding with regard to materiality, but dissented with regard to the fraud-on-the-market issue. The Chief Justice and Justices Antonin Scalia and Anthony Kennedy did not participate in the disposition of the case.

Upon subsequent reconsideration, the Court may erode the fraud-on-the-market doctrine established by the Basic four-to-two plurality decision. The three Justices who recused themselves in Basic have shown a general antipathy toward extending the private right of action under 10b-5. Cf. R. Clark, Corporate Law 316 (1986) (stating that, in 1975, "the Supreme Court, recently coustituted to have a conservative majority, maugurated a series of securities law holdings whose common theme seeined to be that plaintiffs always lost"). Moreover, Justice Brennan's plurality vote may be changed by his replaceinent on the Court, Justice David Souter. 
future profits. ${ }^{5}$ Part II first examines how informational and fundamental efficiency relate to the Supreme Court's analysis of fraud-onthe-market theory. Second, it considers different beliefs about how these two independent dimensions of market efficiency affect the fiduciary relationship desired by shareholders and, consequently, a broad spectrum of corporate regulation. If markets are not both informationally and fundamentally efficient, shareholders will want managers to act in ways that would partially replicate their trading opportunities in a more efficient stock market. ${ }^{6}$

\section{The Corporate Lie}

"To tell the truth is a duty; but it is a duty only in respect to one who has a right to the truth."

\section{A. Default Choice}

In an excellent recent article, Jonathan Macey and Geoffrey Miller argue that the fraud-on-the-market theory is theoretically defensible, but that its application to the specific facts of Basic was wrongheaded. ${ }^{8}$ Specifically, the authors assert that, from an ex ante perspective, shareholders will at times want their managers to he. ${ }^{9}$ For example, in Basic the false denials of merger negotiations nuay have nicreased the likelihood of the inerger and may have been beneficial to

5 Two earlier articles made the distinction between these two species of efficiency. See Gordon \& Kornhauser, Efficient Markets, Costly Information, and Securities Research, 60 N.Y.U. L. Rev. 761, 766-72 (1985); Wang, Some Arguments that the Stock Market Is Not Efficient, 19 U.C. Davis L. Rev. 341, 344-49 (1986).

6 The managers' role in trying to make the firm's stock belave as if it were trading in an efficient capital market corresponds to the role of transactional lawyers in trying to approximate a world without transaction costs. See Gilson, Value Creation by Business Lawyers: Legal Skills and Asset Pricing, 94 Yale L.J. 239, 243 (1984).

7 Constant, On Pohtical Reactions, 1 France 123 (1797), quoted in I. Kant, Critique of Practical Reason and Other Writings in Moral Philosoplyy 346 (L. Beck ed. and trans. 1949). Immanuel Kant refutes this assertion in Kant, On a Supposed Right to Lie for Altruistic Motives, reprinted in I. Kant, supra, at 346.

8 Macey \& Miller, Good Finance, Bad Economics: An Analysis of the Fraud-on-the Market Theory, 42 Stan. L. Rev. 1059 (1990). Macey and Miller are two of the leaders in analyzing corporate governance issues. Although I criticize certain aspects of their discussion, I sliould stress that I liave benefited from reading not only their Stanford piece, but their other contributions as well. Indeed, Macey's semimal contribution to takeover policy is at the core of my criticisin of his analysis of $10 \mathrm{~b}-5$ liability. See infra note 17 .

9 Id. at 1069-70. 
shareholders generally. ${ }^{10}$ For Macey and Miller, the ability of an efficient market to reflect fraudulent corporate speech should not, by itself, give shareholders a cause of action: even when shareholders reasonably can rely on the workings of the market, managers should be hable ouly if intentional misrepresentations also violate a contractually defined fiduciary duty to shareholders. ${ }^{11}$

Furthermore, froin the premise that courts should provide the terms to the hypothetical corporate contract that the parties would have wanted, ${ }^{12}$ the authors argue that even shareholders who explicitly rely on management misrepresentations should not have a cause of action if the he benefited shareholders as a class. ${ }^{13}$ For example, lying about the positive finding from imitial oil well drillings could facilitate the corporation's purchase of surrounding lands at a low price and thus benefit shareholders as a class, even though individual shareholders may be harmed by selling their shares while the share price is artificially depressed. Macey and Miller argue that shareholders, not knowing whether they would sell during one of these artificially induced depressions, would contract to allow such management misrepresentations because they would be more likely to benefit froin the long-run increased share price. ${ }^{14}$

The authors overlook, however, the implications of being able to contract around any standard-form fiduciary duty. Specifically, they fail to appreciate the default nature of the fraud-on-the-market standard as a contractual provision. A "default rule" fills a gap in a contract but can be contracted around to suit the preferences of the parties. ${ }^{15}$ An "immutable rule," by contrast, cannot be contracted around; therefore, it governs all contracts. ${ }^{16}$

10 Id. at 1072.

11 Id. at 1071 . In so arguing, they implicitly rely on the Supreme Court's analysis in Chiarella v. Umited States, 445 U.S. 222 (1980) (holding that there can be no 10b-5 liability unless the insider lias a fiduciary duty to disclose inside information or refrain from trading).

12 Macey \& Miller, supra note 8, at 1068-69.

13 Id. at 1072.

14 Id. at 1072 . For a discussion of shareholder preferences as to short- versus long-run share price maximization, see infra text accompanying notes $159-68$.

15 Ayres \& Gertner, Filling Gaps in Incomplete Contracts: An Economic Theory of Default Rules, 99 Yale L.J. 87, 87 (1989).

16 Id. In the corporate context, for example, most states allow shareholders to contract around the default of preemption rights in the corporation's articles of incorporation, but minority appraisal rights are an innutable part of any corporate form of business. See Black, Is Corporate Law Trivial?: A Political and Economic Analysis, 84 Nw. U.L. Rev. 542 (1990); 
Macey and Miller do not state clearly whether their proposal to allow managerial misrepresentation constitutes a default rule that would enable shareholders to contract to prohibit such misrepresentation. ${ }^{17}$ Assuming they intended their proposal to be a default rule, their article also fails to address how corporations could contract around the default. Nor does the article consider whether their default choice would affect equilibrium contracting. Although most of their analysis ignores the distinction between default and immutable rules, the possibility of contracting around a duty (or nonduty) of honesty changes substantially the public policy analysis.

As an mitial matter, any legal standard that condones corporate prevarication must be a default. Even accepting the proposition that shareholders will sometimes find it in their interest to allow their managers to lie to the market (and to them), other circumstances will oceur in which it will be in the shareholders' interests to demand honesty. In such circumstances, shareholders surely will want the option of contractually committing their inanagers to honesty. Thus, shareholders should liave the option of warranting the honesty of their managers' speech in the articles of incorporation. ${ }^{18}$ This simply

see generally Bebchuk, The Debate on Contractual Freedom in Corporate Law, 89 Colum. L. Rev. 1395 (1989) (discussing mandatory and enabling aspects of corporate law).

17 This is puzzling because Jon Macey has appreciated the implications of default rule choice in other corporate contexts. See, e.g., Haddock, Macey \& McChesney, Property Rights in Assets and Resistance to Tender Offers, 73 Va. L. Rev. 701, 733-37 (1987); Macey \& McChesney, A Theoretical Analysis of Corporate Greenmail, 95 Yale L.J. 13, 58-60 (1985).

18 Society may have an interest in constraining freedom of contract that leads to excessive amounts of what economists call "signaling." See Ayres, The Possibility of Inefficient Corporate Contracts, - U. Cin. L. Rev. - (forthcoming 1991); Rea, Arm-Breaking, Consumer Credit and Personal Bankruptcy, 22 Econ. Inquiry 188, 196-97 (1984). For a discussion of signaling in the corporate context, see infra text accompanying note 170 . Society might, for example, want to limit the ability of directors to signal their good faith by contracting for criminal liability or corporal punishment if they breacli a warranty of honesty.

The extent to which managers can contract for criminal liability under $10 \mathrm{~b}-5$ was left unresolved by the Supreme Court's recent decision in Carpenter v. United States, 489 U.S. 19 (1987), which affirmed defendant Carpenter's $10 \mathrm{~b}-5$ conviction by an equally divided court. Carpenter seems to establish only that there is at least a default duty not to trade on inside information. See id. at 27 (stating that " "even in the absence of a written contract, an einployee has a fiduciary obligation to protect confidential information obtained durimg the course of his employınent' ") (quoting Snepp v. United States, 444 U.S. 507, 515 n.11 (1980) (per curiam)). The Chiarella opinion, however, seeins to mdicate that the duty to disclose or refrain from trading turns on contractually defined fiduciary duties. See Chiarella v. United States, 445 U.S. 222, 227 (1980) (observing "[t]hat the relationship between a corporate insider and the stockholders of his corporation gives rise to a disclosure obligation"). But see id. at 246 (Blackmun, J., dissenting) (stating that lie "would find petitioner's conduct fraudnlent 
recasts the gains from freedom and flexibility of contract. At a minimum, managers should be able to end each assertion with the promise: "Cross my heart and hope to pay civil dainages if I'm lying."

Appreciation that the Macey and Miller standard needs to be a default rule leads us to consider more carefully the alternative default of warranting honesty. The question then becomes: Which is the superior default rule, a "warranty of honesty" or a "no warranty" default? The ability of corporations to opt for either alternative crucially affects the credibility of corporate speech and, consequently, the market's response. Once corporations have the option of cominitting to honesty, the market will discount severely unwarranted, or "as is," statements carrying no corporate warranty.

Macey and Miller seem to appreciate the negative inferences that the market can draw from silence. They write at length about the "no comment" dilemma in which corporations bound to honesty, but wanting to keep merger negotiations secret, must respond "no comment" when asked about a possible takeover. ${ }^{20}$ The market has come to imterpret the "no comment" response to questions concerning merger negotiations as a "yes," so that the managers cannot effectively avoid answering the question. ${ }^{21}$ The authors suggest that allowing corporate management to he will solve this problem:

As the information processors within the capital markets have become more sophisticated, the old fashioned "no comment" statements that management used to make im order to protect confidential information no longer suffice to protect shareholder wealth. In hight of current decoding techniques among market professionals, management must be free to take bolder steps. ${ }^{22}$

The bolder steps of lying will not, however, eliminate the "no comment" dilemma if corporations retain an option of warranting their

within the ineaning of . . Rule $10 \mathrm{~b}-5 \ldots$, even if he had obtained the blessing of his employer's principals before eınbarking on his profiteering scheme") (citation omitted).

19 Ayres \& Miller, "I'll Sell It to You at Cost": Legal Methods to Promote Retail Markup Disclosure, 84 Nw. U.L. Rev. 1047, 1072 (1990).

20 Macey \& Miller, supra note 8, at 1072-73.

21 Id. at 1073.

22 Id. at 1091. The authors' assertion that current decoding techniques have made the "no comment" response outmoded is unsupported. If the stock narkets were efficient in the 1960 s, why was there not just as much a "no comment" problem then? Macey and Miller do not provide an account of how or why the technology of the "infornation processors" became more sophisticated. 
speech. A manager who denies a nerger negotiation but refuses to warrant the denial will be no better off than one who refuses to comment. As long as the corporation has the option of committing to honesty, the niarket will be able to draw the sanie negative inferences from the failure to commit that it currently draws from silence or a "no comment" response. The nuarket will suspect a he when corporations fail to warrant the honesty of their managers' statenients.

Indeed, the prospect of 10b-5 hability might be insufficient to convince market participants that managers speak honestly. Under a variant of the $S E C$ v. Texas Gulf Sulphur $\mathrm{Co}^{23}$ facts in which valuable mimeral deposits are found, shareholders niay prefer that the corporation he to the market even if shareholders who sell during the pendency of the misrepresentation can successfully sue for damages. ${ }^{24}$ In the terminology of Guido Calabresi and A. Douglas Melamed, 10b-5 damages nay represent a "hability rule" protecting corporate shareholders' entitlement to honest statements, but not giving market participants property protection. ${ }^{25}$ Rule $10 \mathrm{~b}-5$ damages, in other words, nay not be high enough to commit faithful corporate managers to honesty. ${ }^{26}$ The nuarket, realizing the incentives of nuanagers to he, ${ }^{27}$ may consequently discount the truthfulness of speech when damages flow only to shareholders selling during the pendency of the he. ${ }^{28}$ The

23401 F.2d 833 (2d Cir. 1968) (en banc), cert. denied, 394 U.S. 976 (1969).

24 For example, assume that the drilling news indicates that the corporate stock is worth $\$ 50$ inore per share but that lying about the drilling for a nionth would allow the corporation to increase the stock value by an additional $\$ 20$ per share, by buying surrounding land nore cheaply. Then all shareholders would want their nuanagers to he even if it neant reimbursing current shareholders (either $\$ 50$ or $\$ 70$ ) who happen to sell during the pendency of the lie.

25 See Calabresi \& Melamed, Property Rules, Liability Rules, and Inalienability: One View of the Cathedral, 85 Harv. L. Rev. 1089, 1105-06 (1972); Haddock, McChesney \& Spiegel, An Ordinary Economic Rationale for Extraordinary Legal Sanctions, 78 Calif. L. Rev. 1 (1990).

26 Indeed, to the extent that $10 \mathrm{~b}-5$ liability is insufficient to deter corporate dishonesty, Macey and Miller should, but do not, argue that viewing such liability as insurance is consistent with their view of hypothetical ex ante contracting. Under this view, shareholders would want their managers to lie where necessary to preserve corporate opportunities, but also would favor compensation for shareholders who sell during the pendency of the hie at an artificially reduced price.

27 The incentives of nranagers to lie will be restricted severely even here, however, if they are held personally hable for misrepresentations. The Securities and Exchange Commission's (SEC) attempt to limit corporations' ability to indemnify nranagers for violating federal securities laws thus nuay increase the credibility of the corporate warranty of honesty. See SEC, Release No. 40-13181 (SEC proposal to limit ability to indemnify against 10b-5 hability).

28 The possibility that current $10 \mathrm{~b}-5$ damages may be insufficient credibly to conmit to honesty might create incentives for firms to contract for higher potential damages to increase 
market's unraveling of "as is" speech may not be complete in that a failure effectively to commit to honesty may not tell the market exactly how and whether the management is lying. An appreciation of the parties' ability to contract for alternative legal standards reveals, however, that there is no easy way to overcome the "no coinment" problem. ${ }^{29}$

Macey and Miller generally assert that courts should adopt the legal standard that the shareholders would have adopted in a hypothetical contract. ${ }^{30}$ Yet even under this standard it is difficult to argue that the majority of shareholders would not prefer a default that warranted honesty. If lawmakers chose a default of no warranty, a majority of corporations likely would adopt resolutions guaranteeing the veracity of their managers' statements. Only by passing such resolutions could corporations keep the market from severely discounting their managers' statements. After all, even before the federal seeurities laws mandated honest disclosure of financial statements, firms attempted to precommit to honesty by hiring independent account-

the market's faith. For an analysis of the public policy implications of contracting for higher damages, see supra note 18 .

29 Macey and Miller's analysis also is flawed because it does not imcorporate a limiting principle regarding the size of the lie. Their argument that managers might faithfully he about merger negotiations might be extended to more egregious hies about the value of the firm. Under their analysis, to increase the profitability of making a bid, managers might go further and lie to depress the already undervalued pre-tender offer price. A corporate he, for example, that the company was to incur huge losses could depress temporarily the market price of the stock and allow the potential bidder to buy at an even larger discount on the open market the five percent of the target company's shares permitted under the Williams Act, 15 U.S.C.A. $\S 78 \mathrm{~m}(\mathrm{~d})(1)$ (West 1981 \& Supp. 1991). Yet determining the reasonableness of managers' actions, even under the forgiving business judgment rule, would require consideration of less restrictive alternatives. See generally $R$. Clark, supra note 4, at 123-29 (discussing inanagers' duty of care and the business judgment rule). There would be at least one less restrictive alternative to such a lypothetical corporate he: The sale of treasury stock to a potential bidder at a discounted price could similarly encourage a bid without the disparate ex post treatınent of shareholders. See Ayres, Analyzing Stock Lock-Ups: Do Target Treasury Sales Foreclose or Facilitate Takeover Auctions?, 90 Colum. L. Rev. 682, 684 (1990).

30 Macey \& Miller, supra note 8, at 1068-69. Their analysis of the hypothetical contract assumes that shareholders would bargain for the contract that would give thein the highest expected value. Diversified shareholders wishing to maximize their minimum return would be able to choose investments with less systematic risk. According to Irving Fisher, shareholders would want their managers to maximize expected return for a given level of systematic risk. I. Fisher, The Theory of Interest 223 (1930). For a summary of Fisher's separation theorem, see infra text accompanying notes 184-86. For a qualification to this separation result, see infra text following note 186 . 
ants to verify their truth. ${ }^{31}$ Choosing a default of guaranteed honesty, then, would save corporations the trouble and cost of adding (and third-parties the trouble and cost of reading) provisions of the articles of incorporation.

Even if most corporations would not contract around a "no warranty" default, however, it is equally, if not more, likely that a majority would elect not to contract around a warranty of honesty. Affirmatively opting for dishonesty would send perverse siguals to the inarket. If a majority of corporations fails to contract around either standard, it becoines impossible, as a matter of theory, to choose the inajoritarian rule becausc the majority of corporate contractors will accept either default. The indeterminacy of using a inajoritarian standard for default choice is further evidence that a majoritarian standard is not well-suited to selecting efficient defaults. ${ }^{32}$ Instead, efficiency-minded lawmakers should choose the default that minimizes the costs of contracting and failing to contract. If few people would contract around either the warranty or no-warranty defaults, the analysis thus quickly devolves to a question about the costs associated with failure to contract around either rule.

A warranty default is more likely to minimize these "failure-to-contract" costs by providing better informed, therefore more efficient, rehance by the inarket. A default of guaranteed honesty that only could be contracted around with speech-specific disclaimers would give market participants better information about the "rules of the gaine." If shareholders benefit from managers' dishonesty because the market fails to understand that the corporation has opted for no warranty, then lawmakers reasonably may establish defaults that promote better informed communication. ${ }^{33}$ Like the Federal Trade

31 See Watts \& Zimmerman, Agency Problems, Auditing, and the Theory of the Firm: Some Evidence, 26 J.L. \& Econ. 613, 629 (1983).

32 See Ayres \& Gertner, supra note 15, at 112-17.

33 Id. at 105 . When histeners do not understand the rules of the game, speakers can fraudulently induce inefficient reliance. For example, in Lefkowitz v. Great Minneapolis Surplus Store, Inc., 251 Minn. 188, 86 N.W.2d 689 (1957), the Supreme Court of Minnesota allowed the defendant to escape liability for refusing to sell fur coats that he had advertised as "Wortl to $\$ 100.00$ " for " $\$ 1$ Each." Id. at 189,86 N.W.2d at 690 . Perversely, if readers failed to understand the rules of the game-that sucl advertisements are too indefinite to constitute binding offers-then these meffective offers may fraudulently induce customers to travel to the store. See Ayres \& Gertner, supra note 15, at 106. 
Commission's rule regulating used car sales, ${ }^{34}$ forcing managers to state clearly when their stateinents are to be taken "as is" without warrant of truthfulness would proinote more efficient reliance. Thus, even if the majority of shareholders would want a no-warranty default, efficiency-minded lawmakers might choose to impose a warranty default to promote better information about who bears the consequences of dishonesty. ${ }^{35}$ In sum, a default that warrants honesty is superior to a no-warranty default because (1) more firms will contract around a no-warranty default; and (2) those firms that fail to contract around a no-warranty default may induce inefficient markct reliance on misrepresentations. To come to any other legal result would be especially perverse because the prime thrust of federal securities laws has been encouraging the dissemination of rehable information. ${ }^{36}$

It is more difficult, however, to establish the exact contours of a default of warranted honesty. ${ }^{37}$ Whereas I argued above that most corporations would contract to warrant their public statements about past "hard" information, it is less certain that corporations would find it in their interest to warrant statements as to "soft" information-for example, predictions of future profits. Shareholders might prefer that, at times, their managers talk about the corporation's future prospects without the specter of securities fraud hability if the prediction does not come to pass. Extending the warranty of honesty to cover species of soft and imphicit representation may lead to the problem of inefficient silencing, which occurs when corporations remam silent not to preserve a corporate opportunity, but to avoid the specter of inefficient lawsuits. The SEC responded to such concerus in 1979 by

34 Used Motor Vehicle Trade Regulation Rule, 16 C.F.R. $§ 455$ (1990).

35 At times, efficiency-minded lawmakers should intentionally disregard the preferences of the contracting parties in establishing default rules. See Ayres \& Gertner, supra note 15, at 106-07. Such "penalty" or "information-forcing" defaults are chosen to encourage private parties to contract around thein and thereby reveal information about their preferences. Id. at 97. Jack Coffee has einployed the notion of information-forcing defaults in arguing that managers' fiduciary duties should be strengthened. See Coffee, The Mandatory/Enabling Balance in Corporate Law: An Essay on the Judicial Role, 89 Colum. L. Rev. 1618, 1623 (1989).

36 See, e.g., SEC v. Ralston Purina Co., 346 U.S. 119, 124 (1953) (holding that the Seeurities and Exchange Act of 1933 was intended "to proteet mvestors by promoting full disclosure of information thought necessary to informed investment decisions") (citation omitted).

37 See infra text accoinpanying notes $191-94$ (discussing colnpeting policy considerations in formulating $10 \mathrm{~b}-5$ damages rules). 
adopting Rule $175^{38}$ under the 1933 Act and Rule $3 \mathrm{~b}-6^{39}$ under the 1934 Act, both of which reheve corporations of federal securities fraud hability for "forward-looking statements" 40 made with a "reasonable basis" and in "good faith." 41 Thus, it is more difficult to know, for example, whether corporations would contract for a requireinent that plaintiffs prove defendant scienter to recover dainages for a warranty breach. ${ }^{42}$

As before, however, efficiency-minded lawmakers should not be guided solely by hypothetical contract considerations. Majoritarian default rules may be unpossible to fashion or may lead to inefficient resource allocations. The appropriate contours of a warranty default-along such dimensions as scienter and materiality ${ }^{43}$ - should be informed more by the debilitating effects of silencing. A default that warranted honesty might avoid the imefficiency of silencing by putting listeners on notice that certain species of information are not susceptible to prosecution under the antifraud provisions. ${ }^{44}$

Of course, choosing a warranty default will not eliminate the "no comment" problem. But an immutable rule that allowed corporations to he ex post in their shareholders' interests would solve the "no cominent" problein ouly by denying firms the ability to precommit to honest speech. Reducing the ability of corporations to speak credibly to the inarket imduces costs that are likely to outweigh significantly

38 Liability for Certain Statements by Issuers, 17 C.F.R. $\$ 230.175$ (1990).

39 Liability for Certain Statements by Issuers, 17 C.F.R. $\$ 240.3 b-6$ (1990).

40 The regulations define the following, inter alia, as forward-looking statements: "a projection of revenues, incoine (loss), earnings (loss) per share"; a "statement of management's plans and objectives for future operations"; and a "statement of future economic performance." 17 C.F.R. $\$ \$ 230.175$ (c)(1)-(3), 240.3b-6(c)(1)-(3) (1990).

41 See R. Jennings \& H. Marsh, Securities Regulation 1014-15 (1987).

42 The federal securities laws in effect provide both types of warranty provisions. Rule 10b5 actions under the 1934 Exchange Act require proof of defendant scienter, Ernst \& Ernst v. Hochfelder, 425 U.S. 185, 212 (1976), but actions under $\$ \S 11$ and 12 of the 1933 Securities Act do not. See 15 U.S.C. $\S 77 \mathrm{k}(\mathrm{b})(3)$ (1988) (dispensing with proof of scienter in favor of negligence standard for section 11 cases); 15 U.S.C. $\S 77 l$ (1988) (same as to $\S 12$ cases).

43 Restricting the warranty's coverage to knowing or intentional misrepresentations may serve as an evidentiary substitute for an inquiry into whether the misrepresentation was material, i.e., likely to induce detrimental reliance. The intentionality of the misrepresentation (scienter) is itself probative of the fact that at least the speakers thought the issue in question was material.

44 For example, such a default miglit force managers to preface portions of oral or written remarks with the disclaimer: "The following is a forward-looking statement that will not give rise to causes of action for misrepresentation or omission." 
the cost of the "no comment" problem. This is especially true because precommitting never to respond to questions im general, or questions regarding mergers im particular, is a more effective, direct way for firms to prevent the market from drawing negative inferences from their refusals to comment. ${ }^{45}$ If the corporate bylaws mandate that managers cannot answer questions (that is, that managers must always give a "no comment" response), then markets cannot draw negative inferences from a "no comment." As long as firms retain the option of warrantimg statements, listeners will draw negative inferences from failures to warrant. The market im a sense appreciates the moral hazard of selective honesty, just as much as selective "no comments." Thus, only by precommitting never to respond can the corporation deny the market this selective signal. ${ }^{46}$

Indeed, lawmakers can do more to solve the "no comment" problem by clarifying how corporations can precommit to silence. Although certain leading federal cases have appreciated that nondisclosure of material facts can serve legitimate corporate objectives, ${ }^{47}$ they have failed to offer procedural safe harbors for precommitting to

45 Corporations listed on the national exchanges may have difficulty committing to such a policy because of exchange rules that mandate disclosure of certain types of information or in response to excliange requests. E.g., 2 N.Y. Stock Exch. Guide (CCH), Rule 416, ๆף 2416(a) \& (c) (1989) (bimding members and member organizations to respond truthfully to New York Stock Exchange request for information "deem[ed] essential for the proteetion of investors and the public interest"). Moreover, Item 303 of Regulation S-K mandates disclosure of specified financial and operational information that may preclude precommitments to silence on tlrose topics. Management's Discussion and Analysis of Financial Condition and Results of Operations, 17 C.F.R. $\$ 229.303$ (1990).

46 In lier excellent book, Sissela Bok reached a similar conclusion in discussing the policy consequences of a government's decision falsely to deny a prospective currency devaluation or tax increase:

$[\Pi]$ is far better to refuse comment than to lie im such situations. The objeetion may be made, however, that a refusal to comment will be imterpreted by the press as tantamount to an admission that devalnation or higher taxes are very near. Such an objection has force only if a government has not already establisled credibility by letting it be known earlier that it would never comment on such matters, and by strictly adlering to this policy at all times.

S. Bok, Lying: Moral Choice im Public and Private Life 178 (1978). For Bok, precommitting to silence is a superior way of overcoming the "no comment" problem, the negative inferences that the press or the market might draw from silence.

47 See, e.g., SEC v. Texas Gulf Sulplur Co., 401 F.2d 833, 857 n.24 (2d Cir. 1968) (en banc) (recognizing that "it could well be desirable ... to preserve when necessary the secrecy of corporate activity, not to require that an insider possessed of undisclosed material information reject the offer of a stock option"), cert. denied, 394 U.S. 976 (1969); see also Basic, 485 U.S. at 234-35 (same). 
nondisclosure. In Basic, the plurality explicitly declined to provide such guidelines:

It has been suggested that given current market practices, a "no comment" statement is tantamount to an admission that merger discussions are underway. That may well hold true to the extent that issuers adopt a policy of truthfully denying merger rumors when no discussions are underway, and of issuing "no comment" statements when they are in the midst of negotiations. There are, of course, other statement policies firms could adopt; we need not now advise issuers as to what kind of practice to follow, within the range permitted by law. ${ }^{48}$

Because the range of "no comment" pohcies permitted by law is unclear, corporations face needless uncertainty in determining whether charter provisions committing corporations to silence would be judicially enforced. ${ }^{49}$ Judicial or regulatory rulemaking that estabhished safe-harbor procedures for precommitting to silence would be inore effective in solving the "no comment" problein than Macey and Miller's proposal.

It is unportant to remeinber that the "no comment" problein is not confined to the corporate context. ${ }^{\text {so }}$ Buyers and sellers often have private information about the value of a commodity that might be valued by the other side of the contract. Indeed, the "no comment" problein

48 Basic, 485 U.S. at 239 n.17 (citation omitted).

49 This is particularly true because the affirmative duty of corporations to disclose is vague. Although courts and commentators often recite that there is no general duty of disclosure, see, e.g., J. Brown, The Regulation of Corporate Disclosure 31 (1990), federal securities law requires certain affirmative disclosures of material developments in reports filed with the SEC. See SEC Enforcement Chief Warns Companies, CPAs on Management Discussion, Analysis, 16 Sec. Reg. \& L. Rep. (BNA) 95, 95-96 (Jan. 13, 1984). In addition, corporations may have a duty to speak the full truth and to ensure the continued aceuracy of past representations. See First Va. Bankshares v. Benson, 559 F.2d 1307 (5th Cir. 1977), cert. denied, 435 U.S. 952 (1978); Cochran v. Channing Corp., 211 F. Supp. 239 (S.D.N.Y. 1962). Several of the national stock exchanges have adopted rules that largely abrogate the general rule of nondisclosure. See J. Brown, supra, at 35; see also Jordan v. Duff \& Phelps, Inc., 815 F.2d 429 (7th Cir. 1987) (holding that closely held firm had duty to disclose material information to investors whose holdings it sought to purchase), cert. dismissed, 485 U.S. 901 (1988); Minpeco, S.A. v. Conticommodity Serv., Inc., 552 F. Supp. 332 (S.D.N.Y. 1982) (holding that an affirmative duty exists to disclose manipulative practice).

50 I an thankful to Tom Jackson, Paul Mahoney and Bob Scott for alerting me to the broader contractual context. 
arose in the oft-cited case of Laidlaw v. Organ. ${ }^{51}$ In that case, Organ, knowing that a treaty ending the War of 1812 would end the British naval blockade of New Orleans (and thus increase the value of exportable commodities), entered into an agreeinent to buy tobacco. ${ }^{52}$ Before agreeing to sell the tobacco, an einployee of Peter Laidlaw \& Co. asked "if there was any news which was calculated to enhance the price or value of the article about to be purchased."53 The record does not reflect, however, what response, if any, Organ inade to this inquiry. ${ }^{54}$ Organ thus was faced with the same dilemma that confronted the inanagers in Basic and the Texas Gulf Sulphur hypothetical: If Organ deiried that he had heard any news, he would have committed fraud, and if he refused to comment, the buyer might have drawn negative inferences. ${ }^{55}$

One could extend the Macey and Miller argument to apply to just this type of traditional fraud case as well. Their argument suggests that an individual who has discovered mimerals should be able to he to neighboring landowners in negotiating to purchase surrounding land. Requiring honesty would allow the neighbors to free ride on the original investinent in drilling. Requiring the initial driller to respond "no comment" is insufficient to protect this informational investment because of the negative inferences that the listener would draw froin such a response. ${ }^{56}$ Following Macey and Miller's logic, courts should not impose a duty of honesty on the knowledgeable buyer, at least when an honest "no comment" would undermine efficient investinent in information, because courts should not inipose on buyers a duty for

5115 U.S. (2 Wheat.) 178 (1817). See generally Coleman, Heckathorn \& Maser, A Bargaining Theory Approach to Default Provisions and Disclosure Rules in Contract Law, 12 Harv. J.L. \& Pub. Pol'y 639, $692-707$ (1989) (discussing "nondisclosure doctrine" in reference to Laidlaw); Kronman, Mistake, Disclosure, and the Law of Contracts, 7 J. Legal Stud. 1, 9-18 (1978) (same).

52 Laidlaw, 15 U.S. (2 Wheat.) at 183.

53 Id.

54 Kronman, supra note 51, at 10. The district court found no evidence that Organ "had asserted or suggested anything ... to induce him to think or beheve that [the news inquired about] did not exist." Laidlaw, 15 U.S. (2 Wheat.) at 183.

55 Kronman, supra note 51 , at 10 n.27. Organ's ability to sell in the face of Laidlaw \& Co.'s inquiry without lying suggests that the "no comment" problein is not insurmountable in all circunstances. The availability of such means of protecting private information, short of outright lying, undermines Macey and Miller's argument that misrepresentations are necessary tools for protecting corporate opportunities.

56 See supra text accompanying note 21 . 
which buyers and sellers would not contract. In the hypothetical drilling case, surrounding landowners should have been willing to contract ex ante, that is, before the drilling, with the driller either not to ask any questions or to waive their right to sue for misrepresentations about the results of the drilling.

Yet to see this analogy to the broader contractual setting is to refute the underlying argument. In arguing for a contractual foundation for corporate fiduciary duties, the authors ignore the copious analysis of contractual fraud that universally accepts a duty that material representations must be truthful. ${ }^{57}$ The time-honored acceptance of this duty in all other contracts is strong evidence in favor of the honesty default, and against Macey and Miller's proposal.

\section{B. Good lies and bad lies}

Macey and Miller also argue that 10b-5 hability should turn on whether the prevaricating corporation will interualize the costs of the misrepresentation. They argue.that if the misrepresentation depresses the value (or maintains an artificially low value) of the stock, then it will raise the lying corporation's cost of capital. ${ }^{58}$ Misrepresentations that raise a corporation's cost of capital are good hes becanse, with the social costs of lying internalized, managers are well-placed to assess whether these costs outweigh the benefits to their shareholders. ${ }^{59}$ In particular, Macey and Miller maintain that "to the extent they were beheved, the defendants' misrepresentations in Basic caused the price of Basic shares to trade at artificially low levels, thus raising the costs to Basic of attracting new capital." $" 60$ Because of this internalization effect, they argue that telling good hes should not subject corporations or their managers to fraud hability. ${ }^{61}$ On the other hand, misrepresentations that raise the stock price are bad hes, in their view, because such misrepresentations decrease the lying firm's cost of capital, thereby allowing the firm to avoid bearing the social

\footnotetext{
57 See, e.g., R. Posner, Economic Analysis of Law 97 (3d ed. 1986).

58 Macey \& Miller, supra note 8, at 1075.

59 Id. at 1075-76.

60 Id. at 1075.

61 Id. at 1076.
} 
costs of lying. ${ }^{62}$ As the costs of bad lies are not internalized, the authors argue that such hes sliould be actionable. ${ }^{63}$

This cost-internalization distinction is triply flawed. ${ }^{64}$ Firms that artificially lower their stock price may not internalize the social costs of their lying through higher costs of new capital because: 1 ) the firm may not need additional capital; 2) lowering the stock price need not

62 Id. at 1075-76.

63 Id. at 1076.

64 The effect of management misrepresentation on the cost of corporate capital can be more formally analyzed if the capital markets are both fundamentally efficient and semi-strong form informationally efficient. See infra text accompanying note 103 (defining and contrasting these two independent dimensions of efficiency). These assumptions of efficiency imply that the market value of the firm will equal the market's best estimate, conditioned on available information, of the net present value of future earnings (PV):

$$
P V=\sum_{i=0}^{\infty} \frac{e_{t}}{(1+r)^{i}}
$$

In this equation, " $e$ " represents the expected earnings of the firm in period " $t$ "; "r" represents the risk-adjusted rate of return (used to discount future earnings), derived from the Capital Asset Pricing Model (CAPM). See R. Brealey \& S. Myers, Principles of Corporate Finance 173-99 (3d ed. 1988). CAPM predicts that a firm's discount rate will be a function of the undiversifiable risk associated with owning the firm's assets. This undiversifiable risk is captured in CAPM by a firm's " $B$ " (beta), the covariance of the firm's returns with the systematic risk of a well-diversified portfolio. Specifically, CAPM predicts a firm's riskadjusted rate of return as:

$$
r=r_{f}+B\left(r_{m}-r_{f}\right)
$$

where " $r_{\mathrm{f}}$ " represents the risk-free rate of return; " $r_{\mathrm{m}}$ " represents the market rate of return; and " $\beta$ " measures the degree to which the firm participates in (covaries with) the systematic (or undiversifiable) risk of the market.

Use of these assumptions of market efficiency and CAPM makes possible more formal evaluation of Macey and Miller's cost-of-capital analysis. A misrepresentation by managenent can reduce a firm's value in the net present value equation by either reducing the expected earnings of the company in future periods (which decreases the numerator in the equation) or by increasing the firm's risk adjusted rate of return (which increases the denominator of the equation). Misrepresentations that reduce a firm's stock price can increase the number of shares that firms need to issue in order to raise a certain amount of funds. Contrary to Macey and Miller, however, neither effect need raise the capital cost per share or the capital cost of corporations ( $r$. Misrepresentations that reduce the firm's value by lowering expected earnings (the numerator effect) need not increase the cost of raising additional capital because the firm's beta, hence the risk adjusted rate of return (demanded by inarket investors), would remain the same. Indeed, even if the misrepresentation increased the beta on the firm's existing assets (the denominator effect), the cost of raising additional capital need not increase because the capital cost for a new investunent is determined solely by the riskiness of that individual investment projeet, the project-specific beta. R. Brealey \& $S$. Myers, supra, at 198 ("Each project should be evaluated at its own opportunity cost of capital; the true cost of capital depends on the use to which the capital is put."). Thus, even misrepresentations that increase the rate at which current investments are discounted should 
increase the cost of additional capital; and 3) even if the cost of capital increases, there is no reason to think that the amount of increase will be proportionate to fraudulently induced rehance expenditures of third parties.

Misrepresentations cannot increase a firm's cost of capital if the firm does not need to borrow from the external capital markets. A large proportion of corporate investment comes from the accumulated retained earnings of corporations. In the 1980 s, for example, between sixty and eighty percent of all corporate investment came from internally generated cash. ${ }^{65}$ Even if a firm needs to go to an external capital market, however, there is no reason to think that a misrepresentation that lowers the stock value will necessarily increase the cost of capital. Certainly, as a general matter, a decline in the price of a company's stock need not increase the cost of capital to a firm, because a healthy firm might continue to borrow at the prime rate of interest both before and after the false statement.

Finally, even if the corporation's cost of capital increases, there is no reason to expect that these increased costs will match the costs of third-party market participants who detrimentally rely on the management misrepresentation. Lying that either inflates or deflates a

not increase the cost of capital on future investments unless these misrepresentations also signal a higher beta for the additional projects.

There is another sense, however, in which misrepresentations might be said to increase a firm's cost of capital, and that is by increasing the amount of firm leverage. By reducing the market value of a firm, negative news about future earnings will reduce the firm's stock value inore than its bond value (unless the firm is highly leveraged). Negative news then will increase the firm's leverage by increasing the market valuation of its debt/equity ratio. If the Modigliani-Miller Irrelevance Theorem is correct, this misrepresentation-induced change in leverage will have no effect on the firm's cost of capital for the simple reason that a firm's total cost of capital is not dependent on the amount of the firm's leverage, i.e., debt/equity ratio. See Modighiam \& Miller, The Cost of Capital, Corporation Finance and the Theory of Investment, $48 \mathrm{Am}$. Econ. Rev. 261 (1958).

Because of the costs of taxation and financial distress and market imperfections, however, the conclusions of the Modigliani-Miller theorem inay not hold, so a firm's costs of capital may in fact depend on the amount of leverage. Under these circumstances, misrepresentations that change the amount of leverage affect the costs of a firm's existing capital by either increasing or decreasing the risk-adjusted rate of return that is demanded by market investors. Management misrepresentations that increase a firm's leverage under this theory could increase the firm's implicit cost of a firm's existing capital. Yet, even viewing Macey and Miller's assertion most charitably, there is no reason to suspect that management misrepresentations will affect either firm leverage or investment-specific betas in ways that have any nexus with the social costs of lying.

65 See R. Brealey \& S. Myers, supra note 64, at 312-13. 
stock's price will induce third parties to expend resources that would be avoided if inanagers had instead credibly committed to honesty. ${ }^{66}$ If courts accept this good he/bad he distinction, theu market analysts will spend more resources atteinpting to verify unwarranted claims by manageinent that the firm's stock price is undervalued. In the end, the amount of these reliance costs likely will be coinpletely independent of the increased capital costs of prevaricating corporations. Therefore, the authors' cost internalization argument cannot be sustained.

The inore relevant distinction is not whether the he increases or decreases the stock price, but whether market participants clearly understand the rules of the game. Even hes that inflate a stock's price should be allowed as long as the market has clear notice that the corporate speech inust be taken "as is," with no warrant of veracity. As long as a corporation warns the market that its managers' statements may be untrnthful, then the market rehes on these stateinents at its own risk. As long as the rules of the game are clearly known, the corporation fully internalizes the costs of its decision not to commit to honesty. For example, if a corporation fails to warrant the statements of its inanagers, it will have to expect that the inarket will discount statements to the effect that the firm is "in play." This may destroy the gains of inaking such statements when they are trne, but, counter to Macey and Miller, this Article argues that such statements should be allowed as long as the market fully understands whether they are backed by a warranty of honesty.

The authors' failure to realize this point is all the more surprising because Jon Macey has inade a dramatically similar argument in otler corporate writing. ${ }^{67}$ For instance, in "Property Rights in Assets and Resistance to Tender Offers," Macey teamed with David Haddock and Fred McChesney to argue that target inanagers should be allowed to resist tender offers because, as long as potential bidders know that resistance is possible, the target corporation will bear the cost of failing to precommit to passivity. ${ }^{68}$ Failure to precommit to

66 Macey and Miller note, for example, that if management fabricates a rumor that the firm is "in play" (that it is the object of takeover interest), "[p]otential bidders will waste resources sifting through the false information." Macey \& Miller, supra note 8, at 1075.

67 See, e.g., Haddock, Macey \& McChesney, supra note 17; Macey \& McChesney, supra note 17.

68 Haddock, Macey \& McChesney, supra note 17, at 726. 
passivity puts third parties on notice that the target corporation may free ride on the investment of the initial bidder by resisting takeover bids. ${ }^{69}$ This potential for free riding lowers the likelihood that a potential bidder will investigate or bid on a firm; consequently, it may lower the value of a firm that fails to precommit to nonresistance. ${ }^{70}$ In the earlier article, Macey and his coauthors concluded that, because the corporation internalizes the costs of failing to commit, it is well-placed to decide whether the benefits of resistance outweigh the costs of failing to commit to passivity. ${ }^{71}$

This analysis of passivity precommitinent bears striking similarity to this Article's analysis of precommitments to honesty. Corporations should have the choice of precommitting to honesty; given the choice, a corporation that does not precommit to honesty puts third parties on notice that they rely on managers' statements at their own risk. As with the passivity precommitment choice, the corporation is wellplaced to determine whether retaining the option to he outweighs the relative costs of the negative market reaction to the failure to warrant.

In sum, Macey and Miller correetly argue that corporations may at times find it in their interests to he to the market. Giving corporations the ability to opt for honesty, however, drastically reduces the range of instances where "as is" speech will be profitable. Because inarkets will draw negative inferences from unwarranted denials of merger negotiations, a failure to warrant speech is no better than an honest refusal to comment. Shareholders inight want their nianagers to be able to trick the market, but in a world in which firms can precommit to honesty, the opportunities for profitable unwarranted inisrepresentation are severely limited. Moreover, as a matter of default choice, the current default of warranting honesty seems superior to the no-warranty default because few corporations would contract around a warranty of honesty, and those that would inight induce inefficient rehance by market participants who inistakenly rely on "as is" speeeh as warranted. ${ }^{72}$

Instead of distniguishing between good and bad hes, it is inore relevant for law to estabhish a clear default rule-and procedures for contracting around the rule-that informs the market whether a given

69 Id. at 723.

70 Id.

71 Id. at 736.

72 See supra note 33 . 
corporation has precommitted to honesty. As long as the market knows whether the corporation stands behind the truth of its managers' statements, then the corporation will internalize the costs and benefits of a failure to commit, and third-party market participants will avoid mefficient rehance costs.

\section{Market EfFiciency AND CORPORATE SPEech}

The Basic Inc. v. Levinson ${ }^{73}$ decision implicitly reaffirms the analysis of the last Section: Basic holds, at a minimum, that management umisrepresentations are actionable in the absence of any corporate agreement to the contrary. ${ }^{74}$ More controversially, however, Basic exphicitly changes traditional standing requirements by allowing plaintiffs who have not actually heard the corporate he to claim that they detrimentally relied on the integrity of the market to reflect such information. This Part of the Article distinguislies between two independent dimensions of inarket efficiency- "informational" and "fundamental" efficiency ${ }^{75}$-and shows how different conceptions of efficiency underlie the plurality and dissenting opinions in Basic. More generally, this Part argues that behefs about whether the stock market is informationally or fundamentally efficient will determine shareliolder preferences concerning corporate speech. The degrec of market efficiency will affect not only shareliolders' agency relationship with management, but also how efficiency-minded lawinakers clioose to regulate a wide range of corporate issues.

73485 U.S. 224 (1988) (plurality opinion).

74 Because the Court allowed the plaintiffs' case to go forward in the absence of a specific contractual provision imposing on management the duty to inform the shareholders that inerger negotiations were underway, its holding in Basic suggests that 10b-5 liability is at least a default rule. It is unclear, however, whether current interpretations of $10 \mathrm{~b}-5$ would allow corporations to contract around a warranty of honesty and, if so, what would be sufficient contractually to accomplish this end. See, e.g., Jordan v. Duff \& Phelps, Inc., 815 F.2d 429, 436-37 (7th Cir. 1987) (opining in dicta that even insider trading prohibitions are inerely default rules that corporate employment contracts could negate), cert. disınissed, 485 U.S. 901 (1988).

75 The failure to distinguish between these two dimensions of efficiency has clouded thc discussion of the inuplications of the Efficient Capital Markets Hypothesis (ECMH) for corporate law. See Gordon \& Kornliauser, supra note 5, at 828 (1985). 


\section{A. Two Dimensions of Market Efficiency}

\section{Informational Efficiency}

In accepting the fraud-on-the-inarket presumption of $10 \mathrm{~b}-5$ standing, the Basic plurality seeins to rely largely on the Efficient Capital Markets Hypothesis (ECMH). ${ }^{76}$ The ECMH predicts that security markets will be informationally efficient in that stock prices will reflect certain classes of existing information. ${ }^{77}$ The ECMH supports a presumption of fraud-on-the-market standing: if "the market price of shares traded on well-developed markets reflects all publicly available information," it will also reflect material misrepresentations. ${ }^{78}$ Thus, even without knowledge of the misrepresentations, former shareholders can claim that they would have sold their shares at a different price, but for the misrepresentation.

Whereas this simple theory has plausibility, it requires further identification of the specific form of efficiency that, as a logical matter, must underlie tlie fraud-on-tle-market presumption. The ECMH can take three distinct forms: ${ }^{79}$ The "weak form" postulates tliat current stock prices reflect all information concerning past price clianges; ${ }^{80}$ the "semi-strong form" posits that current stock prices reflect all pub-

76 Basic, 485 U.S. at $246-47$ n.24. In so doing, the Supreme Court followed other scholarsand the majority of lower federal courts-who have argued that the ECMH provides adequate grounds for giving shareholders standing even if they have not heard the false corporate statements. See, e.g., Fischel, Use of Modern Fimance Theory in Securities Fraud Cases Involving Actively Traded Securities, 38 Bus. Law. 1 (1982); Note, The Fraud-on-the-Market Theory, 95 Harv. L. Rev. 1143 (1982); Note, Fraud on the Market: An Emerging Theory of Recovery Under SEC Rule 10b-5, 50 Geo. Wash. L. Rev. 627 (1982). But see Black, Fraud on the Market: A Criticism of Dispensing with Reliance Requirements in Certain Open Market Transactious, 62 N.C.L. Rev. 435 (1984) (arguing that traditional concepts of reliance and causation have validity in certain market contexts). For a representative listing of the lower courts that have adopted some form of the fraud-on-the-market doctrine, see Basic, 485 U.S. at 247 n.25.

77 See Basic, 485 U.S. at $246-47$ n.24. ("market professionals generally consider most publicly announced inaterial statements about companies, thereby affecting stock prices").

78 Id. at 246.

79 Although Eugene Fama chanipioned the terminology and elaborated this tripartite distinction, he credits Roberts for the original contribution. Fanı, Efficieut Capital Markets: A Review of Theory and Einpirical Work, 25 J. Fin. 383, 383 n.1 (1970); see R. Brealey \& S. Myers, supra note 64, at 287 (citing H. Roberts, Statistical Versus Clinical Prediction of the Stock Market (May 1967) (unpublished nnanuscript presented to the Seminar on the Analysis of Security Prices, Umiversity of Chicago)).

80 Fania, supra note 79, at 414. 
lic information; ${ }^{81}$ and the "strong form" posits that current stock prices reflect not just all public information, but all existing (public and nonpublic) information. ${ }^{82}$

Only the semi-strong formulation of the ECMH supports fraud-onthe-market standing. ${ }^{83}$ The strong-form formulation cannot constitute the basis for the doctrime because it assumes that the stock price would reflect all existing information, "mcluding the fact that the stateinents issued by Basic were false." 84 Analogously, the doctrine cannot be based on the weak-form formulation because that view guarantees only that the stock price will reflect information about past prices. Weak-form efficiency would not, by itself, predict that management misrepresentations affect stock price. ${ }^{85}$ Thus, to justify sliareliolder reliance on false public statements, the fraud-on-tlie-market theory requires acceptance of the semi-strong formulation of the ECMH.

This insight was originally made by Dan Fisclel and reiterated shortly thereafter by Macey and Miller. ${ }^{86}$ Their contribution reveals witl greater clarity the detailed assumptions that the Supreme Court must accept in upholdimg the doctrime's use. Botli articles, lowever, fail to test these assumptions against the newest theoretieal and empirical learning. The empirical section of Macey and Miller's article, for example, cites primarily to statistical studies written in the 1960 s and 1970s. From this historical vantage, it was not surprising for the autliors to conclude that the semi-strong formulation of market efficiency is " "now an accepted working assumption in financial economics researcl1." "87 Indeed, in 1978, Micliael Jensen, a leading

81 Id.

82 Id.

83 See Macey \& Miller, supra note 8, at 1077 (asserting that "the [Basic] Court was adopting the semi-strong version of the efficient capital markets hypothesis"); see also Fischel, Efficient Capital Markets, The Crash, and the Fraud on the Market Theory, 74 Cornell L. Rev. 907, 911 (1989) (also referring to the Basic Court's adoption of the semi-strong version of the efficient capital markets hypothesis).

84 Macey \& Miller, supra note 8, at 1078.

85 Id. at 1079 (noting that, under weak-form ECMH, "plaintiffs could not reasonably rely on the market price of a security to reflect all publicly available information about the relevant firm").

86 See Fischel, supra note 83, at 911; Macey \& Miller, supra note 8, at 1077-79.

87 Macey \& Miller, supra note 8, at 1082 (quoting J. Lorie, P. Dodd \& M. Kimpton, The Stock Market: Theories and Evidence 73 (2d ed. 1985)). 
finance economist, was able to write that "the efficient markets hypothesis is the best established fact in all of social sciences." 88

In the last five years, however, each formulation of the ECMH has come under sustained empirical and theoretical attack. Andrei Shleifer and Lawrence Summers recently wrote:

If the efficient markets hypothesis was a publicly traded security, its price would be enormously volatile. Following Samuelson's (1965) proof that stock prices should follow a random walk . . . and Fama's (1965) demonstration that stock prices are indeed close to a random walk, stock in the efficient markets hypothesis rallied. . . . But the stock in the efficient markets hypothesis-at least as it lias traditionally been formulated - crashed along with the rest of the market on October 19, $1987 .{ }^{89}$

In addition, a number of authors have proposed theoretical models of "noise traders" in which soine investors react to nonfundamental news, or noise, thereby creating nonrandoin fluctuations in share prices. $^{90}$

Einpirically, recent studies have deinonstrated a tendency for stock prices to be "mean-reverting" in the sense that stocks with high returns today tend to have lower future returns. ${ }^{91}$ This result directly contradicts the weak and semi-strong versions of the ECMH by show-

88 Shleifer \& Summers, The Noise Trader Approach to Finance, J. Econ. Persp., Spring 1990 , at 19, 19 (attributing, without citation, quoted statement to Jenseu).

89 Id.

90 See, e.g., Black, Noise, 41 J. Fin. 529 (1986); Kyle, Continuous Auctions and Insider Trading, 53 Econometrica 1315 (1985). Perversely, noise traders can earn higher expected returns because they take on more risk; accordingly, the normal operation of market forces nay not drive such traders froin the inarket. See Shleifer \& Summers, supra note 88, at 24-25. Moreover, arbitragers may find it in their interests to mimic noise traders during the initial state of overbuying or overselling. See De Long, Shleifer, Summers \& Waldmann, Positive Feedback Investıneut Strategies and Destabilizing Rational Speculation, 45 J. Fin. 379, 380 (1990). The noise trader model suggests-and the suggestion recently has beeu proved accurate-that the discounts on closed-end mutual funds correlate negatively with the returns of small capitalization stocks, because the investor sentiment of similar individual investors dominates both inarkets. See Lee, Shleifer \& Thaler, Anomalies: Closed-End Mutual Funds, J. Econ. Persp., Fall 1990, at 153, 154.

More sophisticated defenses of fundamental efficiency focus, inter alia, on the impact snall changes in expected growth can have on present discounted values of future cash flows. See, e.g., Barsky \& De Long, Bull and Bear Markets in the Twentieth Century, 50 J. Econ. Hist. 265 (1990).

91 See Fama \& French, Permanent and Temporary Components of Stock Prices, 96 J. Pol. Econ. 246 (1988); Poterba \& Summers, Mean Reversion in Stock Prices: Evidence and Implications, 22 J. Fm. Econ. 27 (1988). 
ing that public price information can help predict future price changes. Other empirical studies document tendencies for short-term positive correlations im returns on particular stock prices. ${ }^{92}$

These recent findings call into question Basic's presumption of rehance. Increasmgly, Justice Byron White's adınonition im dissent rings true: 'For while the economists' tlieories which underpm the fraudon-the-market presumption may have the appeal of mathematical exactitude and scientific certainty, they are-in the end-nothing more than theories which may or may not prove accurate upon further consideration."93 Notwithstanding these recent powerful critiques of the $\mathrm{ECMH}$, the legal presumption of semi-strong form efficiency for stocks traded on the national exchanges may still be warranted, although the critiques clearly militate in favor of more circumscribed confidence in it.

\section{Fundamental Efficiency}

There is a separate dimension of market efficiency that commentators routinely and mistakenly imterchange with the various forins of the ECMH. The ECMH concerns whether a stock market is "informationally" efficient: that is, whether the current inarket price immediately reflects different categories of existing infornation. Market efficiency, however, can also refer to whether the market is "fundamentally" efficient: that is, whether, conditioned on the inforination available, the market price exclusively reflects the underlying, or fundamental, profits of the corporation. ${ }^{94}$ This distinction between informational and fundamental efficiency dates back at least as far as John

\footnotetext{
92 See D. Cutler, J. Poterba \& L. Summers, Speculative Dynamics, Working Paper No. 3242, Nat'l Bureau of Economic Research, Inc. (Jan. 1990) (unpublished manuscript) (on file with the Virginia Law Review Association); DeBondt \& Thaler, Further Evidence on Investor Overreaction and Stock Market Seasonality, 42 J. Fin. 557 (1987).

The ECMH is also contradicted by: (1) the tendency of share prices to increase by two to three percent when a stock is included in the Standard \& Poor's 500 Stock Index, see Harris \& Gurel, Price and Volume Effects Associated with Changes in the S \& P 500 List: New Evidence for the Existence of Price Pressures, 41 J. Fin. 815 (1986); Shleifer, Do Deinand Curves for Stock Slope Down?, 41 J. Fin. 579 (1986); and (2) the tendency of small stocks to outperform inarket indices by a significant percentage each January, see Ritter, The Buying and Selling Behavior of Individual Investors at the Turn of the Year, 43 J. Fin. 701 (1988); see also Wang, supra note 5 , at $349-62,377-94$ (discussing recent studies undercutting informational efficiency assumption of ECMH).

93 Basic, 485 U.S. at 254 (White, J., dissenting).

94 See infra note 97.
} 
Maynard Keynes, ${ }^{95}$ but often is still muddled or forgotten by legal commentators who erroneously claim that the ECMH imphes fundamental efficiency. ${ }^{96}$

Fundamental efficiency posits that, conditioned on the information available, stock prices will reflect the present value of corporations' expected underlying profits. ${ }^{97}$ In a fundamentally efficient market, news about sunspots or the price of tea im China should not affect the

95 J.M. Keynes, The General Theory of Employment, Interest and Money 153-57 (1936). In a famous passage, Keynes compared the stock market to a beauty contest:

$[P]$ rofessional investment may be likened to those newspaper competitions in which the competitors have to pick out the six prettiest faces from a hundred photographs, the prize being awarded to the competitor whose choice most nearly corresponds to the average preferences of the competitors as a whole; so that each competitor has to pick, not those faces which he himself finds prettiest, but those which he thinks likeliest to catch the fancy of the other competitors, all of whom are looking at the problem from the same point of view. It is not a case of choosing those which, to the best of one's judgment, are really the prettiest, nor even those which average opinion genuinely thinks the prettiest. We have reached the third degrce where we devote our intelligences to anticipating what average opinion expects the average opinion to be.

Id. at 156. More recently, Nobel-laureate economist James Tobin has admonished that one form of efficiency does uot necessarily iniply the other. Tobin, On the Efficiency of the Financial System, 153 Lloyds Bank Rev. 1, 5 (1984); see Fischel, supra note 83, at 913; Wang, supra note 5 , at 344 .

96 Two nisightful legal articles, however, do appreciate and explicate this distinction. Gordon \& Kornhauser, supra note 5, at 825 (defining informational and fundamental efficiency as "speculative" and "allocative" efficiency); Wang, supra note 5, at 344-49 (defining analogous efficiency terms of "information-arbitrage" and "fundamental-valuation"). Much of the accompanying text at most elaborates their previous insights.

Fischel, supra note 83, at 912-13, makes a similar distinction betwecn "tradimg-rule efficiency" and "value efficiency." Trading-rule efficiency incorporates informational efficiency by focusing "on the speed with which market prices reflect publicly-available information and whether the price reaction to new information is without bias." Id. Bias in a price reaction cannot be mcasured, however, without relation to some benchmark of fundamental or intrinsic value, so Fischel's efficiency categories are not entirely distinct. As defined by Fischel, tradingrule efficiency iniplies that "it is inupossible to devise a trading rule that systematieally outperforms the market (net of transaction costs) absent possession of inside information." Id. at 913. By focusing on the absence of profitable arbitrage opportunities, this definition fails to ensure either informationally or fundamentally efficient inarkets. Tradimg-rule efficiency, for example, cannot distinguish between the semi-strong and strong form versions of the ECMH. Although arbitrage is an inportant mechanism of market efficiency, see Gilson \& Kraakman, The Mechanisms of Market Efficiency, 70 Va. L. Rev. 549, 553 (1984), the absence of profitable arbitrage opportunities is not sufficient to guarantce that stock prices will reflect existing information or fundamental value, sec infra note 108.

97 More formally, fundamental efficiency requires that a stock price equal the present discounted value of a corporation's expected earnings, where future earnings are discounted by the risk-adjusted rate of return of the Capital Asset Pricing Model. See supra note 64 (net present value equation). Expectations about earnings are formed on the basis of information 
stock price of IBM.98 Taken to its extreme, fundamental efficiency implies that a decision by the president of Northwestern University to sell a liuge block of Xerox stock for the sole and stated purpose of building a new football stadium slould not affect the price of that stock. Because the sale provides no information about the underlying profits of Xerox, the market should have ready, willing, and able buyers to soak up this unexpected supply of shares without letting the stock price drop a fraction of a point. ${ }^{99}$

In addition, fundamental efficiency determines how nuuch a stock price should nove in response to a piece of news. If a corporation trading in a fundamentally efficient market unexpectedly earns an extra one million dollars, then its stock price should increase by one million divided by the number of outstanding shares. ${ }^{100}$ The enipirical finding that stock prices exhibit substantially greater volatility than underlying dividends suggests that the niarket may respond to fundamental news in nonfundamental ways. ${ }^{101}$ Pieces of news nuay

that is available to the market. The degree of informational efficiency determines what existing information is "available" to the market. See infra text accompanying note 106.

98 Authors have claimed that sunspots correlate with the business cycle. See, e.g., Jevons, Commercial Crises and Sun-Spots, in Investigations in Currency \& Finance (2d ed. 1909); Gordon \& Kornhauser, supra note 5, at 807; Sheehan \& Grieves, Sunspots and Cycles: A Test of Causation, 48 S. Econ. J. 775 (1982).

99 Thus, taken to this extreme, fundamental efficiency inplies that the market demand for stock at its fundamental price should be horizontal. See Shleifer, supra note 92, at 579; Stout, Are Takeover Premiums Really Premiums? Market Price, Fair Value, and Corporate Law, 99 Yale L.J. 1235, 1236-37 (1990).

100 In this regard, the stock market's response to the Texaco-Pennzoil hitigation, for example, poses a conundrum for those who behieve in fundamental efficiency. On Friday, April 10, 1987, Texaco filed for bankruptcy after a Texas jury awarded Pennzoil \$10 billion in damages against Texaco for Texaco's interference with Pennzoil's attempted takcover of Getty Oil. On the next trading day, Monday, April 13, the stock price of both Texaco and Pennzoil dropped significantly. See Mnookin \& Wilson, Rational Bargaining and Market Efficiency: Understanding Pennzoil v. Texaco, 75 Va. L. Rev. 295, 332 (1989). The news of Texaco's bankruptcy reduced the total value of Texaco and Pennzoil's assets by approximately $\$ 3.4$ billion. See Summers \& Cutler, Texaco and Pennzoil Both Lost Big, N.Y. Times, Feb. 14, 1988, at F3, col. 1. While some have attributed this result to "market error," see Cutler \& Summers, The Cost of Conflict Resolution and Financial Distress: Evidenee from the TexacoPennzoil Litigation, 19 RAND J. Econ. 157, 158 (1988), others have found it consistent with stock market efficiency. See Mnookin \& Wilson, supra, at 311-15 (arguing, inter alia, that the rational expectation that Texaco would be involved in a lengthy and costly bankruptcy reorganization accounts for the huge equity losses).

101 See Shiller, Do Stock Prices Move Too Much to be Justified by Subsequent Changes in Dividends?, 71 Am. Econ. Rev. 421 (1981) for the first and most controversial analysis of this issue. Shiller's work has sparked a rich debate. See, e.g., Kleidon, Bias in Sinall Sample Tests 
have both fundamental and nonfundamental components in that nonfundamental speculation may cause the market to overreact. The market, alternatively, may overreaet to this piece of fundamental information. Regardless of the semantic characterization, however, this phenomenon refutes the notion that the market is fundamentally efficient because it shows that the market does not move solely to reflect the fundamental content of available information.

Informational and fundamental efficiency in a sense concern the market's supply of, and demand for, information. The degree of informational efficiency represents a "supply-side" attribute that determines what categories of information are made available to the market. In contrast, the degree of fundamental efficiency is a "demand-side" attribute that determines which categories of available information the market values. Informational efficiency determines which information is available to the market; fundamental efficiency determines how the market reacts to this available information. The market's equilibrium reaction to news will be simultaneously determined by both types of efficiency, but, as with other goods, the market's supply and demand of information can be analyzed independently.

The two dimensions of efficiency are diagrammed in Figure 1. The vertical and horizontal lines divide types of existing and future infornation that might affect a stock price. ${ }^{102}$ Figure 1 depicts how informational and fundamental efficiency can be viewed in part as "excluder" theories because they exclude certain classes of information from having a potential impact on future stock price changes. The divisions along the vertical axis capture the different formulations of the informational efficiency of the ECMH. The weak-form hypothesis posits that existing price information (Area A) has no effect on future price changes; the semi-strong form hypothesis posits that

of Stock Price Rationality, 59 J. Bus. 237 (1986); Kleidon, Variance Bounds Tests and Stock Price Valuation Models, 94 J. Pol. Econ. 953 (1986); Marsh \& Merton, Dividend Variability and Variance Bounds Tests for the Rationality of Stock Market Prices, 76 Am. Econ. Rev. 483 (1986).

102 Area B, for example, consists of nonfundamental, public information. An example of sucl information, with respect to IBM's stock, would be the public disclosure that President Ronald Reagan dyed his hair. By comparison, Area D consists of fundamental, nonpublic information. Examples of such information include undisclosed information concerning firmspecific innovations (sucli as cloning a new hormone) or macroeconomic variables (such as last week's Federal Reserve Board activity). 
Figure 1: Two Dimensions of MARKet EFficiency

FUNDAMENTAL EFFICIENCY Nonfundamental Fundamental Information Information
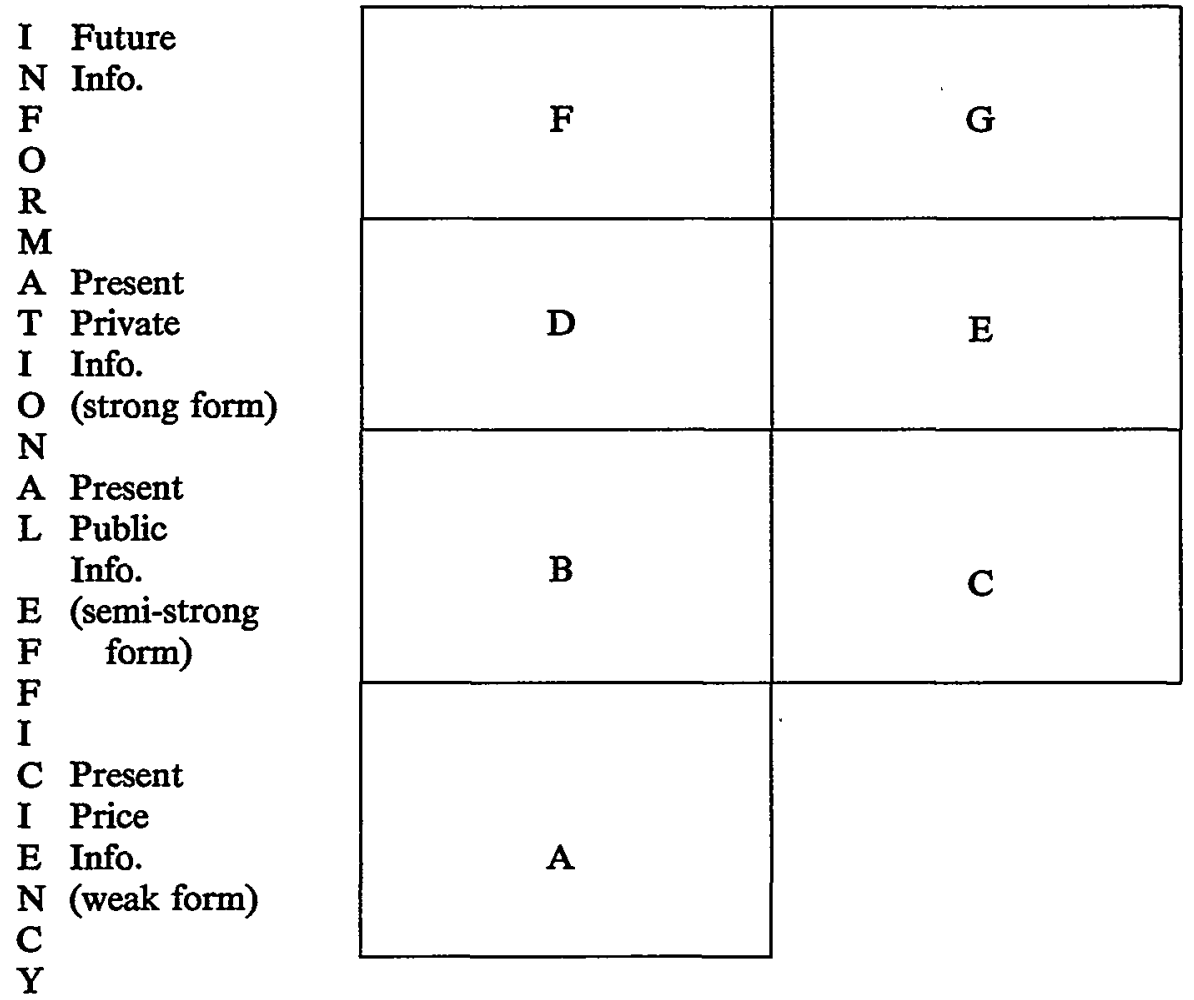

existing public information (Areas A, B, and C) has no effect on future price changes; ${ }^{103}$ and the strong-form hypothesis posits that botli existing public and private information (Areas A, B, C, D, and E) have no effect on future price changes.

The notion of fundamental efficiency, however, cuts this informational pie in a different way. The left-hand column (Areas A, B, D, and $F$ ) includes different types of nonfundamental information, and

103 In Figure 1, the subset of all existing public information would include the subset of existing (past) price information, because information about a traded stock's past price is quintessentially public. 
the right-hand column (Areas C, E, and G) includes different types of fundamental information. ${ }^{104}$ The divisions along the horizontal axis capture whether the market is fundamentally efficient. The fundamental hypothesis posits that nonfundamental information (Areas $A$, $B, D$, and F) has no effect on future stock price changes; ${ }^{105}$ but under the nonfundamental hypothesis, either fundamental or nonfundamental information (Areas $A$ through $G$ ) may affect future price changes. The informational dimension of efficiency determines what information is available for use by the market; the fundamental dimension of efficiency determines what types of information the market considers relevant. ${ }^{106}$ Accordingly, the informational dimension of efficiency cannot speak to the effects of future pieces of news on stock. ${ }^{107}$ Fundamental notions of efficiency, however, can make predictions about the effects even of future information: if the market is fundamentally efficient, then even today we can say that tomorrow's sunspot will not affect stock prices.

Thus, in discussing the efficiency of the stock market, one must distinguish between the two competing types of stock market efficiency and make independent assessments about whether (and to what degree) the market is informationally and fundamentally efficient. ${ }^{108}$

104 The analytic distinction in Figure 1 between fundamental and nonfundamental information is useful in practice to distinguish between core nonfundamental news (including sunspots and the director's zodiac sign) and core fundamental news (including macroeconomic variables such as interest rate changes and firm-specific variables such as a new patent). As discussed above, information with soine relevance to underlying profitability, therefore considered fundamental, but that causes the inarket price to change inore (or less) than warranted by fundamental considerations alone, might have both a fundamental and a nonfundamental coinponent.

105 In Figure 1, only the nonfundamental column of information includes the subset of information concerning existing (past) price information. Past price information does not constitute fundamental information as it contains no information about a firm's future underlying profitability.

106 The legal concept of "material" information is closely related to this definition of fundamental efficiency. See TSC Indus., Inc. v. Northway, Inc., 426 U.S. 438, 449 (1976) (stating that omitted information is material if there is "a substantial likelihood that a reasonable shareholder would consider it important" in inaking an investinent decision).

107 There could not exist a "super-strong" formulation positing that future information would have no effect on future stock prices because, under the various formulations of the ECMH, information not currently available can affect a future stock price.

108 It is possible that extreme forms of informational efficiency may preelude fundamental inefficiency so that the assessinents of these two dimensions of market efficiency inay not be completely iudependent. For example, if the market is strong-form informationally efficient with regard to all existing information, fundamental inefficiency may be inconsistent with 
For example, in Figure 1, a belief tliat the inarket is fundamentally efficient and semi-strong form informationally efficient would imply that ouly the types of information represented in Areas $E$ and $G$ could affect future stock prices. A belief in fundamental efficiency would exclude all nonfundamental information (Areas A, B, D, and F), and a belief in semi-strong form informational efficiency would eliminate all existing public information (Areas A, B, and C).

Without drawing the crucial distinction between fundamental and informational efficiency elaborated above, the respondents in Basic pointed to the stock inarket crasll of October 19,1987, as a reason to question inarket efficiency. ${ }^{109}$ But the dramatic fall of the inarket on Black Monday provides different sorts of evidence witli regard to the separate issues of fundamental and informational efficiency. Black Monday provides strong and direct evidence that tlie New York Stock Excliange (NYSE) is not fundamentally efficient because it is impossible to locate any information that could be responsible for a twentytwo percent devaluation of corporate assets on tliat single day, or a thirty-six percent devaluation froin tlie 1narket's peak in late August. Althougli soine liave tried, ${ }^{110}$ it is difficult to argue tliat news concerning the present value of future underlying profits accounted for the fall. ${ }^{111}$

In sliarp contrast, the dramatic fall does not refute the notion that the market is informationally efficient. After all, the various formula-

notions of arbitrage among a small group of fundamental traders. Cf. supra note 96 (discussing Fischel's notion of "trading-rule" efficiency). Even sunall amounts of informational mefficiency may be sufficient to generate the possibility of nonfundamental pricing. For example, not knowing the amount of liquidity selling or portfolio insurance can lead to price movements that are inconsistent with fundamental efficiency. See infra text accompanying notes 129-38.

109 See supra text accompanying note 3.

110 See, e.g., Lee, Efficient Market Theory Lives!, Wall St. J., May 6, 1988, § 1, at 20, col. 4.

111 See Lowenstein, Casting Out a Plague of Speculation, N.Y. Times, May 11, 1988, at A27, col. 2 (attributing 1987 stock market crash to speculators); Wolman, Efficient Market Theory Stumbles, Fin. Times, Apr. 15, 1988, at I16, (stating that, contrary to ECMH, there are no "cconomic developments to justify" the 1987 stock market crash). The present value of future profits might be sensitive to changing estimates of the growth rate, see Barsky \& De Long, supra note 90 , at 265 , or the risk-adjusted interest rate, see supra note 64 . It is possible that fundamental information regarding these variables could have accounted for some of the stock movement. But if the information "coming to inarket" on those October days is consistent with fundamental efficiency, the New York Stock Exchange should exhibit much more volatility on inany other days when the market receives similar signals but does not react as cataclysmically. 
tions of informational efficiency posit that the current stock price will quickly reflect certain classes of information. It is hard to deny that the stock market prices were changing quickly. Once we discard the notion that the market is fundamentally efficient, it is possible that the stock exchanges were rapidly mcorporating nonfundamental news imto the stock valuations. In sum, the sudden market plunge on Black Monday refutes the fundamental efficiency of the market but may support the notion that the stock market is informationally efficient. ${ }^{112}$

\section{Refinements of Informational and Fundamental Efficiency}

Theories of informational and fundamental efficiency can be refined in two important ways reflecting more particularized treatment of both time and information. First, the benchmark theories of informational efficiency posit that the stock market price will instantaneously reflect certain types of information. Even if we reject the notion that a certain class of information is immediately absorbed into the price of stock, we could beheve that a strong tendency exists for the market to reflect such information within a certain period of time. Thus, even though it is unlikely that the market is instantaneously strong-form efficient, ${ }^{113}$ nonpublic information may have a strong tendency to become public through various market and social forces, ${ }^{114}$ so that we could believe that stock prices will reflect any nonpublic information that has existed for, say, twelve months. ${ }^{115}$

Secondly, the degree of informational and fundamental efficiency can be further detailed by more finely distinguishimg between different classes of information. ${ }^{116}$ Just as the ECMH distinguishes between three different classes of information to establish three different forms of informational efficiency, we may liave grounds for further subdivid-

112 See Fischel, supra note 83, at 915.

113 See, e.g., Grossman \& Stiglitz, On the Impossibility of Informationally Efficient Markets, 70 Am. Econ. Rev. 393, 395 (1980).

114 See, e.g., Klein, Merger Leaks Abound, Causing Many Stocks To Rise Before the Fact, Wall St. J., July 12, 1978, \& 1 at 31 , col. 1 .

115 See infra text accompanying notes $159-66$ (analyzing implications of a strong-form efficient inarket "with one period lag").

116 See Gilson \& Kraakman, supra note 96, at 556 (observing that "scholars have pressed the weak, semi-strong, and strong form categories beyond their original service as a classification of empirical tests into more general duty as a classification of market responses to particular kinds of information"). 
ing each efficiency dimension. For example, stock prices may reflect certain types of public information (concerning, for instance its own prices, or the interest rate on Treasury Bills) faster than other types of public information (concerning, for example, Iraq's invasion of Kuwait). In such circuinstances, saying that the inarket is or is not semi-strong form informationally efficient provides hittle help. Instead, better pohcy might result froin a inore particularized understanding of how fast the inarket assimilates various types of information.

Our appreciation of fundamental efficiency might also benefit froin further subdividing the horizontal axis of Figure 1. Within the class of nonfundamental information, one can easily distinguish information concerning the hquidity of the stock inarket froin other types of nonfundamental information. Suppose, for example, that upon waking up toinorrow we learn that a boinb has destroyed half the trading capacity of the New York Stock Exchange for the next year. ${ }^{117}$ This information is not fundamental because it does not pertain to the underlying profits of the traded stocks. ${ }^{118}$ It is likely, however, that stock prices will fall because investors in thin inarkets will probably include a hquidity discount in their valuation of the security. ${ }^{119}$ The hquidity of stock ownership has been repeatedly extolled as a fundainental attribute of the corporate form; ${ }^{120}$ it is thus hardly surprising that impairing ownership hquidity reduces stock value.

117 One can readily think of other discrete events that might affect market liquidity: the federal government might impose a significant transfer or turnover tax on stock sales; a stock excliange miglit limit the volume of stock traded under certain conditions; or an individual corporation could issue rights that lost value if the stock were traded or clianged hands too many times per period.

118 Information bearing on liquidity could be thought to be "fundamental" if we abandon the Capital Asset Pricing Model (CAPM) as the sole determinant of the appropriate discount rate. In a multifactored asset pricing model, hquidity could affect the risk-adjusted rate of return demanded by investors, including the hquidity risk of investment. Ross, The Arbitrage Theory of Capital Asset Pricing, 13 J. Econ. Theory 341, 351 (1976). The discount rate, in turn, affects the net present value of an investment. See supra note 64. Regardless of how one characterizes these hiquidity effects, their presence will cliange the objectives of inanagers seeking to maximize the corporation's current stock price.

119 See R. Conroy \& K. Eades, The Pricing Characteristics of Convertible Preferred Stock 3 (Feb. 1991) (unpublished manuscript) (asserting that common stock "commands a hquidity premium" over less liquid convertible shares).

120 See R. Clark, Corporations 14 (1986); Easterbrook \& Fischel, Limited Liability and the Corporation, 52 U. Chi. L. Rev. 89, 111 (1985). 
Market-liquidity effects on stock prices represent a special class of nonfundamental valuation, because they are not susceptible to traditional types of arbitrage. Most theories of nonfundamental valuation are based on speculative models in which an expectation of a higher resale price primarily motivates imvestors. ${ }^{121}$ On this assumption of investor motivation, nonfundamental pricing theories posit that expectations of future price imcreases can lead speculators to drive the current stock price above its fundamental value. ${ }^{122}$ These speculative deviations from fundamental values are often called "bubbles." 123 The term is evocative because speculative deviations, like bubbles, tend to "pop" as investor arbitrage eventually punctures the expectations of ever-increasing prices. ${ }^{124}$ Market-hquidity effects on stock prices are not, lowever, speculative bubbles that can be punctured by arbitrage. Changes in the liquidity or thickness of the market should reduce resale opportunities. As long as there is a positive probability that investors will need to sell their shares while the market is illiquid, the stock price will be discounted. ${ }^{125}$

The stock market may have so mucli excess liquidity, lowever, that news about relative amounts of illiquidity never impairs resale opportunities and accordingly has no effect on stock prices. Two recent examples powerfully contradict this view and suggest that illiquidity discounts can significantly affect stock prices. Market illiquidity seemed to play a prominent role in the 1987 market collapse as the securities markets' limited capacity to liandle the demand for trades led to dramatic price reductions. When the New York Stock

121 See, e.g., Feiger, What is Speculation?, 90 Q.J. Econ. 677 (1976); Harrison \& Kreps, Speculative Investor Behavior in a Stock Market with Heterogeneous Expectations, 92 Q.J. Econ. 323 (1978).

122 See Stiglitz, Symposium on Bubbles, J. Econ. Persp., Spring 1990, at 13, 13.

123 According to a recent definition, "if the reason that the price is high today is only because investors beheve that the selling price will be high tomorrow-when 'fundamental' factors do not seem to justify such a price-then a bubble exists." Id. at 13.

124 See Blanchard, Speculative Bubbles, Crashes and Rational Expectations, 3 Econ. Letters 387, 388 (1979); Stighitz, supra note 122, at 14.

125 Andrei Shleifer and Lawrence Summers detail the himits of arbitrage: "[T]here are several reasons ... to assume that arbitrageurs have short horizons. Most importantly, arbitrageurs have to borrow cash or seeurities to implement their trades, and as a result must pay the lenders per period fees." Shleifer \& Summers, supra note 88, at 21; see also Shleifer \& Vishny, Equilibrium Short Horizons of Investors and Firms, 80 Am. Econ. Rev. 148, 152-53 (1990) (stating that arbitragers will avoid long-term arbitrage because of the greater risks and positive externalities involved and because it takes longer to reap the gains of such arbitrage). 
Exchange hit its capacity constraint, stock prices took a free-fall. ${ }^{126}$ Hitting the stock market's trading capacity did not constitute fundamental news because it did not relate to any of the corporations' underlying profitability, yet investors' reaction to news of illiquidity seems to have caused, at least in part, the market's reaction. ${ }^{127}$ This nonfundainental explanation eerily parallels the precipitous price drops on Black Tuesday, October 29, 1929: "When the stock ticker ran late, mvestors panicked and sold their holdings." 128

A number of recent articles have shown that beyond these exchange capacity constraints, markets may exhibit illiquidity because uninformed mvestors may be unwilling to absorb an unanticipated supply of stocks to be sold. ${ }^{129}$ For exainple, in an elegant inodel, Gennotte and Leland have shown that "[i]f there are relatively few informed imvestors, inarkets may be much less hiquid (and therefore more fragile) than traditional models predict when unobserved supply shocks occur." 130 In their model, one small group of investors (priceinformed investors) may, like insiders, receive some information about the firm's future fundaniental value; another small group of imvestors (market-makers) may receive some information about the ainount of "hquidity selling" that is taking place; ${ }^{131}$ and the largest group of investors can only observe the current stock pricc. In this model, if an unusually large supply of stock to be sold exists, and if the market-makers cannot ascertain whether this supply comes from

126 See Report of the Presidential Task Force on Market Mechanisms (1988) [hereinafter the Brady Report].

127 The market's response to illiquidity may have had both speculative and nonspeculative components. It would be hard to argue that the $22 \%$ decline on Black Monday was caused solely by a nonspeculative illiquidity discount.

128 White, The Stock Market Boom and Crash of 1929 Revisited, J. Econ. Persp., Spring 1990, at 67, 68 (1990); see J.K. Galbraith, The Great Crash (1988); C. Kindleberger, Manias, Panics and Crashes: A History of Fmancial Crises (1978).

129 Sec Geunotte \& Leland, Market Liquidity, Hedging, and Crashes, 80 Am. Econ. Rev. 999 (1990); Grossman, An Analysis of the Implications for Stock and Futures Price Volatility of Program Trading and Dynamic Hedging Strategies, 61 J. Bus. 275 (1988); J. Grundfest, When Markets Crash: The Consequences of Information Failure in the Market for Liquidity (Sept. 1990) (unpublished manuscript) (on file with the Virginia Law Review Association); C. Jacklin, A. Kleidon \& P. Pfleiderer, Underestimation of Portfolio Insurance and the Crash of October 1987 (unpublished manuscript) (Aug. 1990).

130 Gennotte \& Leland, supra note 129 , at 1001.

131 Liquidity selling is prompted by the need of stockholders to exchange their shares to raise cash for current consumption. Obviously, liquidity selling tells us nothing about the fundaniental value of the firm. 
price-informed investors or liquidity sellers, then the inarket may become illiquid at current price levels and even at price levels substantially below the current price. This illiquidity is caused by the reluctance of uninformed investors to buy from sellers who may have information that the fundamental value of the firm lias fallen:

If supply changes are unobserved, all investors will revise downward their expected future price and will absorb the increased supphies only after price has fallen substantially. Price-informed investors will have soinewhat greater elasticity of demand than uninformed investors, since they receive independent information about future prices. However, their contribution will be minimal if they are few, or if their price information is very noisy.

How . . market-1nakers . . contribute to inarket hquidity ... depends on the quality of the supply signal they observe. When their signal has low precision, they side with the uninformed investors.... Because their actions are not aggressive and their numbers are relatively sinall, inarket-makers with poor supply information will reduce volatility only inarginally. ${ }^{132}$

If the vast majority of shareholders cannot tell whether the seller is selling for fundamental (insider) or nonfundamental (liquidity) reasons, then small amounts of unexpected supply can generate large price falls as uninformed investors refuse to buy froin someone who potentially lias imside information of bad fundamental news.

The existence of unobserved portfolio insurance can dramatically exacerbate this liquidity effect. ${ }^{133}$ Portfolio insurance represents a dynanric leedging strategy whereby investors try to maintain a synthetic put option on their investment. ${ }^{134}$ A syntlietic put option to sell one hundred shares of stock is obtained by selling a certain proportion of one liundred sliares "short"135 and by investing the proceeds from this slort sale and an additional ainount (equalling the cost of the

132 Gennotte \& Leland, supra note 129 , at 1007.

133 Sanford Grossman first explicated this point. See Grossman, Insurance Seen and Unseen: The Impact on Markets, J. Portfolio Mgmt., Summer 1988, at 5.

134 A "put" is an option to sell a security at a stated "exercise" price. Buying a sliare and a put eliminates the down-side risk of investment because, if the share price drops below the put's exercise price, the investor can exercise the option to ensure the receipt of at least the differeuce between the exercise price and the depressed share price. The price of this insurance is the price of the put.

135 The percentage to be sold sliort is commonly referred to as the "hedge ratio" or the "option delta" and can be derived from the Black-Scholes option pricing formula. See $\mathbf{R}$. Brealey \& S. Myers, supra note 64 , at $485-86$. 
put) into a safe interest-bearing security such as Treasury Bills. ${ }^{136}$ To inaintain a synthetic put over time, however, requires the put owner to adjust the proportion of shares shorted as the underlying price of stock changes. Crucially, as the price of stock falls, the owner of a synthetic put needs to sell more shares short. ${ }^{137}$

As Sanford Grossinan originally suggested, portfoho insurance inay have a destabilizing effect because of the inability of the broad class of uninformed shareholders to distinguish between fundainental sales and the sales of investors with portfolio insurance who are selling merely to readjust their synthetic puts. A small price fall (caused by either fundamental news or unobserved hquidity selling) might therefore trigger a price fall akin to Black Monday as portfoho insurers try to sell increasing numbers of shares to readjust their synthetic puts. As Gennotte and Leland describe, uninformed investors might rationally attribute this unexpected portfoho insurance sell-off to insiders or sinart money, who have superior access to information about firms' fundamental value: "Observing these falling prices, uninformed investors (rationally) concluded that highly negative information must have been received by the price-informed imvestors. . . [T] [he inajority of investors stood on the sidelines or bought only limited amounts, consistent with a conviction that something unknown but terrible must have happened." 138 In sum, poor information about the sources of hquidity or dynamic hedging selling can cause inarkets to be relatively illiquid at or near current prices. Information regarding these sources of selling consequently can have a dramatic impact on future price changes in ways that contradict traditional notions of fundamental efficiency.

136 Investors who want to hedge their investment by buying the equivalent of 100 shares and a put option on 100 shares can accomplish this by buying shares plus a synthetic put:

buy 100 shares

sell (delta) $\times 100$ shares

buy specified amount of safe securities, which on net is equivalent to:

buy $(1$-delta $) \times 100$ shares,

buy specified amount of safe securities, where delta is the option delta. See supra note 135 .

137 A rough intuition for why this is true can be gleaned from the fact that, as the price of the underlying stock decreases, the put option goes further "into the money," i.e., it increasingly gains value. In the case of extreme price drops, owning a put deep in the money is equivalent to owning a short share because the owner knows with a high degree of certainty that he or she will exercise the option. Because of this equivalence, as the put goes deeper into the money, the proportion of shorted sales (the option delta) approaches $100 \%$.

138 Geunotte \& Leland, supra note 129 , at 1012. 
One important regulatory response to Black Monday only reinforces the importance of these illiquidity effects in determining stock prices. Since the 1987 crash, the New York Stock Exchange (NYSE), the Chicago Mercantile Exchange (CME) and the Chicago Board of Trade (CBT) have all instituted "circuit-breaker" regulations that halt trading for a prescribed period after a significant fall in market price. ${ }^{139}$ For example, if the Dow Jones Industrial Average drops by 250 points on a smgle day, a NYSE rule mandates a one-hour halt in the trading of all stocks. ${ }^{140}$ Figure 2 charts the use of a circuit breaker on the CME. ${ }^{141}$ On Monday, July 24, 1990, when contracts for the Standard and Poor's Stock Index futures fell twelve points (the equivalent of 100 points in the Dow Jones industrial average), the CME circuit breaker halted trading at lower levels for thirty minutes. ${ }^{142}$

Many suggest that the price inoveinent in Figure 2 deinonstrates the success of circuit breakers: the trading halt allowed the inarket to "cool off and digest information."143 The precipitous decline in the price of futures contracts may have been fueled, however, by the existence of the circuit breaker and the illiquidity it inandates. The early declines in futures contract prices increased the probability that the circuit breaker would be activated. This increased probability had a destabilizing effect as the inarket discounted the security's value because of the impending possibility of illiquidity. It follows that the prospect of illiquidity could have caused the circuit breaker to have a inagnetic effect, pulling down security prices that came too close: "when prices approach a circuit-breaker level, the drop accelerates in a rush to sell before the inechanisin is triggered."144 Thus, the precipitous price decline in Figure 2 provides additional evidence that

139 See S. Rep. No. 300, 101st Cong., 2d Sess., at 37-38 (1990). Congress has recently given the SEC exphicit authority to mandate such circuit breakers. See Market Reform Act of 1990, Pub. L. No. 101-432, § 6, 104 Stat. 963 (1990) (amending 15 U.S.C. § 78(k)(1)-(4) (1988)).

1402 N.Y. Stock Exch. Guide (CCH), II 2080B, Rule 80B (1990).

141 Figure 2 is taken from Shapiro, Circuit Breakers: Maybe They Work, Maybe They Don't, N.Y. Times, July 29, 1990, at F7, col. 1.

142 Id. at F7, col. 2. See Chicago Mercantile Exch. Rule 4002(I) (1991).

143 Shapiro, supra note 141, at F7, col. 3. For discussion of the assumptions about informational and fundamental efficiency that underlie the adoption of circuit-breaker regulation, see supra text accompanying notes 109-12.

144 Shapiro, supra note 141 , at F7, col. 4. 


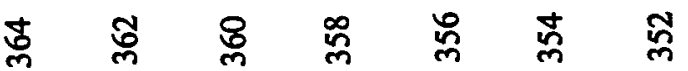

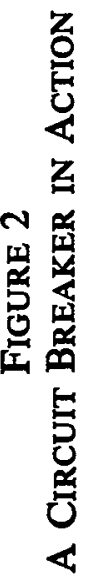

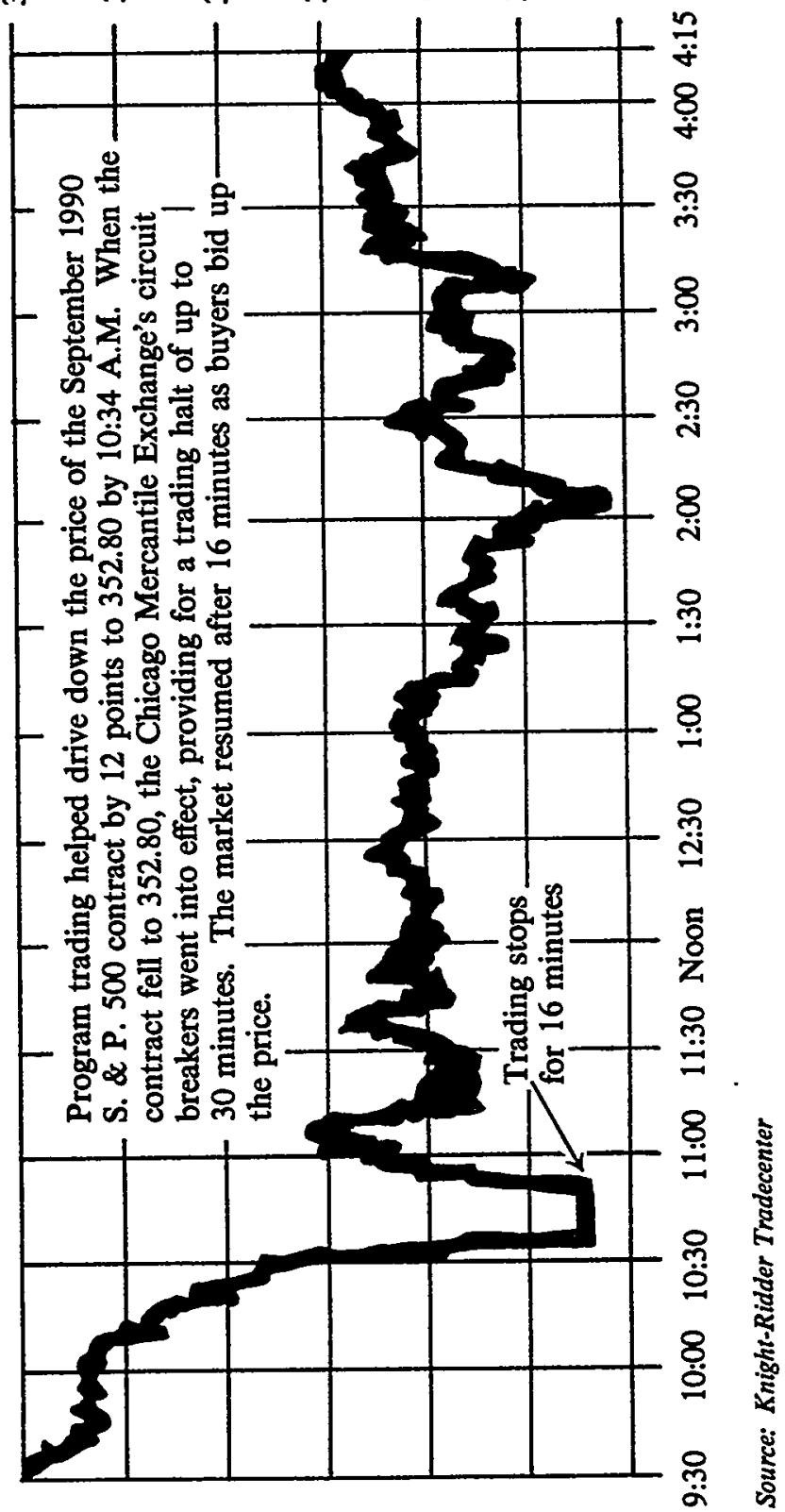


nonfundamental information about market liquidity can affect market price. ${ }^{145}$

\section{B. Basic Views of Efficiency}

An understanding of the analytical distinction betwecn informational and fundamental efficiency allows reconciliation of the disparate judicial interpretations of fraud-on-the-market doctrime. In the Basic opinion itself, the plurality and dissenting opinions do not jom issue on the same concept of market efficiency. Justice Harry Blackmun's plurality opinion focuses on informational efficiency: "Recent empirical studies have tended to confirm Congress' premise that the market price of shares traded on well-developed markets reflects all publicly available information."146

In dissent, Justice Byron White, joined by Justice Sandra Day O'Connor, rejects the conclusion of market efficiency, but in language that sounds in terms of fundamentals:

For in adopting a "presumption of reliance," the Court also assumes that buyers and sellers rely - not just on the inarket price-but on the "integrity" of that price. It is this aspect of the fraud-on-tle-inarket lypothesis which most mystifies ine. ...

To define the term "integrity of the inarket price," the inajority quotes approvingly from cases whicl suggest that investors are entitled to "rely on the price of a stock as a reflection of its value." "But the ineaning of this phrase eludes me, for it implicitly suggests that stocks liave some "true value" that is ineasurable by a standard other than their market price. While the Scholastics of Medieval times professed a ineans to make sucl a valuation of a commodity's "wortl," I doubt that the federal courts of our day are similarly equipped. ${ }^{147}$

145 It follows from the foregoing analysis that the Brady Report's response to the 1987 market crash is particularly benighted. See Haddock, An Economic Analysis of the Brady Report: Public Interest, Special Interest, or Rent Extraction?, 74 Cornell L. Rev. 841 (1989). If, as suggested above, market illiquidity was at least one precipitating factor in Black Monday's free fall of stock prices, then the report's suggestions of increasing the exchanges' capacity and instituting uniform circuit breakers are at cross purposes. Id. at 858, 860-61. Increasing the exchanges' capacity would reduce the likelihood of illiquidity discounts, but imposing circuit breakers would imcrease the likelihood of such illiquidity and, as discussed above, might generate a magnet effect that pulls stock prices down from fundamental value.

146 Basic, 485 U.S. at 246 (plurality opinion).

147 Id. at 255 (White, J., dissenting) (citations and footnotes omitted). 
Justice White, in essence, argues that the fundamental efficiency of the market is unknowable because courts cannot determine, independent of share price, the value (underlying profits) of the corporation. ${ }^{148}$

In other words, the plurality argues in favor of the fraud-on-themarket presumption because it concludes that well-developed stock markets are informationally efficient; the dissent argues against the presumption because it cannot conclude that the market is fundamentally efficient. Yet, as argued above, ${ }^{149}$ these assessinents are not mutually exclusive: it is possible that the inarket is informationally efficient but not fundamentally efficient. ${ }^{150}$ Thus, the question left unresolved by the Justices in Basic must be answered: Which form of efficiency is relevant to the fraud-on-the-market doctrine of $10 \mathrm{~b}-5$ standing?

As a logical inatter, only the semi-strong form of informational efficiency is required to deinonstrate that inanagement misrepresentations affect stock prices. Justice Blackmun imphicitly recognizes this in a footnote: "For purposes of accepting the presumption of rehance in this case, we need only beheve that inarket professionals generally consider inost publicly announced material stateinents about coinpa1nies, thereby affecting stock market prices."151 Thus, even in a 1narket that is not fundamentally efficient (and accordingly pays attention to information unrelated to a corporation's underlying profits), an informationally efficient inarket will tend to generate detrimental price effects when corporations lie.

\footnotetext{
148 See Fischel, supra note 83, at 919-20. The process of measuring fundamental efficiency can become particularly scholastic when one considers that nonfundamental speculation can distort the market price of a corporation's underlying assets. Consider, for example, a corporation that invests only in tulip bulbs. If the spot price for bulbs is determined solely by speculation-the desire to resell the bulbs for a higher price-is it proper to say that a stock market that reflects the higher value of the corporation's underlying assets is fundamentally efficient? For a description of the "tulipmania" that overtook the Netherlands in 1637, sending the price of a single bulb to more than $\$ 16,000$, see C. Mackay, Memoirs of Extraordinary Popular Delusions and the Madness of Crowds (1852).

149 See supra notes 109-12 and accompanying text. id.

150 Indeed, one might take this lesson from the sudden fall im prices on Black Monday. Sec

151 Basic, 485 U.S. at 247 n.24. It is here that Blackmun most effectively counters the new learning on the failings of the ECMH. See supra text accompanying notes 89-92. To justify the Basic presumption, one need not accept that all forms of public information are completely absorbed into the current stock price; one ouly need accept that such information tends to affect price. See Fischel, supra note 83, at 911.
} 
Justice White's analysis does, however, pertain to the amount of damages. For if the market lacks fundamental efficiency (or if this is unknowable), courts lose their ability to determine what the price would have been but for the corporate misrepresentation. ${ }^{152}$ Nor can the Court simply say that understating a windfall profit translates to a particular stock price change. Thus, whereas informational efficiency may justify the plurality's presumption, Justice White's legitimate concerns with the market's fundamental efficiency give defendants yet another basis for rebutting the size of the misrepresentation effect. ${ }^{153}$

\section{Nonfundamental Objectives of Corporate Speech}

Appreciating the fundamental and informational dimensions of market efficiency also allows a clearer conception of why shareholders would want their managers to speak to the market. The imitial Section of this Article, analyzing whether shareholders would precommit to honesty, dealt im a sense with the quality of corporate speech. This Section turns to the issues of the quantity and timing of corporate speech to investigate when shareholders will demand speech from their managers. ${ }^{154}$

Law and economics models of the corporation have proposed two alternative characterizations of what shareholders would like their managers to do. One characterization asserts that shareholders will want managers to maximize the underlying profits of the corporation, or, more precisely, the present discounted value of future profits. ${ }^{155}$ The other characterization suggests that managers should maximize

152 However, even if courts can determine how a nonfundamental market would react to misrepresentations, it is unclear whether securities law should, as a matter of policy, promote speculation concerning nonfundamental information by making that determination. Materiality standards slould exclude nonfundamental information in order to discourage speculation on socially inefficient information such as sunspots. By promoting (or at least not proscribing) nonfundamental fraud, law can help drive this genre of speculation from the market, which would result in efficiency gains to society at large. This possibility is addressed infra, notes 180-83.

153 See generally Carney, The Limits of the Fraud on the Market Doctrine, 44 Bus. Law. 1259 (1989) (discussing other ways to rebut the fraud-on-the-market presumption).

154 For an insightful discussion of similar issues, see B. Black, The Timing of Corporate Disclosure (draft Aug. 14, 1987) (unpublished manuscript) (on file with the Virginia Law Review Association).

155 See, e.g., Bayley, Rule 19c-4: The Death Knell for Dual-Class Capitalizations, $15 \mathrm{~J}$. Corp. L. 1, 25 (1989); Gordon, Ties that Bond: Dual Class Common Stock and the Problein of Shareholder Choice, 76 Calif. L. Rev. 1, 78 (1988). 
the present value of the corporation's stock. ${ }^{156}$ Although corporate scholars often use these two managerial objectives interchangeably, the objectives are only identical if a corporation's stock is traded on an exchange that is both fundamentally efficient and strong-form informationally efficient.

Proving that the two managerial objectives will diverge if the market is not fundamentally efficient is straightforward. For example, if the stock price turns on nonfundamental information (such as the size of accounting profits or charitable contributions), then managers maximizing share price would have reasons to trade-off underlying economic profits to mamipulate these variables. This form of fundamental imefficiency also could cause shareholders to demand corporate expenditures on speech about these topics. To be sure, managers will speak to the market for fundamental reasons: to stimulate demand or reduce costs, especially the costs of capital. ${ }^{157}$ The point here is that when stock price is not determined solely by fundamentals, shareholders will demand some corporate speech for nonfundainental reasons. The existence of fundamental inefficiency thus changes the managerial objectives demanded by shareholders.

Even if the inarket cares only about fundamentals, however, shareholders might still demand that managers pursue objectives other than maximizing profits. Most basically, shareholders might want managers to spend money on conveying information that will reduce the shareholders' need inefficiently to duplicate and verify their managers' statements. The company can often provide corporate information inore cheaply because it has better access to the information and because it only needs to research the information once (saving individual shareholders the cost of developing the information separately). ${ }^{158}$ Thus, shareholders rationally might demand audited financial statements even if auditing reduces underlying profits.

156 See R. Brealey \& S. Myer's, supra note 64, at 22-23.

157 See generally supra note 64 (discussing limited ways in which corporate misrepresentations will affeet the cost of capital in a fundamentally efficient inarket).

158 See Easterbrook \& Fischel, Mandatory Disclosure and the Protection of Investors, 70 Va. L. Rev. 669, 684 (1984) (stating that "[f]or most information about a firm, the firm itself can crcate and distribute the knowledge at less cost than the shareholders"); cf. Coffee, Market Failure and the Economic Case for a Mandatory Disclosure Systein, 70 Va. L. Rev. 717, 733 (1984) (asserting that when information is inade available from a central information repository, "[r]ival firms do not need to incur expenses to produce essentially duplicative data"). 
The following Section focuses on an independent reason why shareholders might demand corporate speech that reduces the underlying profits of the firm. If the market is not informationally efficient in the strong-form sense, shareholders may want their unanagers to expend corporate resources (and accordingly reduce corporate profits) for the sole purpose of changing the stock price. In other words, shareholders may have a nonfundamental demand for corporate speech in that they will want their inanagers to reveal fundamental information to the inarket even when the process of revelation reduces the underlying profitability of the firm. When the stock market is not strongform informationally efficient, then, shareholders may want their inanagers to trade-off underlying economic profits to increase the current stock price.

\section{The Stock Price/Profit Trade-off}

To illustrate this with a simple model, consider a corporation driven by inarket forces to precommit to honesty. ${ }^{159}$ Assume that the corporation's stock is traded on a market that is fundamentally efficient and informationally efficient in the seim-strong sense. Assume further that the inarket is strong-form efficient "with a one period lag." 160 Strong-form efficiency with a one period lag means that, in any period, managers discover information not immediately available to the market, but that the inarket will costlessly learn about this "news" one period later and will then reflect this news in the market price.

We now ask whether shareholders would ever want their nanagement to spend money to talk credibly to the market. ${ }^{161}$ For example,

159 As discussed above, corporations that fail to precommit to honesty may bear the costs of negative inferences as the market discounts the statements of its managers. See supra text accompanying notes 30-32. Alternatively, one could assume that courts have held that federal law immutably mandates managerial honesty. Cf. supra note 36 (stating that congressional purpose behind 1933 Securities Act was to ensure truthful disclosure of material information).

160 This definition grows out of the previous discussion that suggested that theories of informational efficiency could be further refined by gauging the time it takes a given class of information to be reflected in a stock's price. See supra text accompanying notes 113-16.

161 In dramatizing this trade-off between the size of underlying profits and the accuracy of the share price, this model suppresses any effects that corporate speech may have on underlying profits. Speaking to the market may simultaneously enhance a profitable opporturity and increase the price of the stock. See supra text accompanying note 157. For the purposes of this stylized example, however, the "news" is not disclosed to improve the profits of the firm. 
if the corporation's managers stumbled upon information that unexpectedly improves the profitability of the firm, would the shareholders want their managers to spend money to tell the market about it? For specificity, assume that the news imdicates the current stock market price is " $D$ " less than fundamentals would indicate and that managers can credibly communicate the news to the inarket for a per share price of "C." To complete the model, assume that the corporation's shareholders are homogeneous and that a given shareholder has a "P" probability of needing to sell his or her shares in any given period, ${ }^{162}$ which is simply to say that $P$ is the probability that a given shareholder will be a hquidity seller. ${ }^{163}$

If managers do not speak, the current share price will not change, and the stock price will increase by $D$ in the next period when the information becomes available to the market. Because a chance exists that each shareholder will sell his or her share during the first period, the expected value of this information without corporate speech is $P(0)+(1-P) D$, where shareholders who sell (with probability $P$ ) in the first period receive no benefit, and those who sell (with probability $(1-P))$ in the second period after the news leaks to the market receive $D$. With corporate speech, the expected value of the information is $\mathbf{D}-\mathrm{C}$, which represents the fact that commumication immediately increases the value of the corporation by $D$ less $C$, the real expenditure in making the revelation. ${ }^{164}$ Corporate speech ensures that all shareholders, even those who sell their stock in the initial period, share in the good news, but causes all shareholders to bear the cost of disclosure.

Under these conditions, shareholders would want their managers to expend resources if $\mathbf{D}-\mathrm{C}>(1-\mathrm{P}) \mathrm{D}$, which simplifies to $\mathrm{PD}>$ C. ${ }^{165}$ This inequality imphes that managers will sacrifice underlying

162 These unexpected demands for funds in any period generate a randoin need to sell. See Shleifer \& Summers, supra note 88 , at 23 . Several formal economic models of insider trading explicitly rely on the existence of liquidity sellers. See, e.g., Glosten \& Milgrom, Bid, Ask and Transaction Prices in a Specialist Market with Heterogeneously Informed Traders, $14 \mathrm{~J}$. Fim. Econ. 71, 77 (1985); Kyle, supra note 90, at 1315.

163 See supra note 131.

164 This analysis assumes that shareholders who sell in subsequent periods will expect to earn either $D$ (if there is no corporate speech) or D - C (if there is). The randoun-walk hypothesis (weak-form informational efficiency) suggests that current price is the best predictor of future price. See Fama, supra note 79, at 414.

165 Using algebra, D - C > $(1-P) D$ can be rearranged to yield: 
profits when the expected benefits from disclosure (PD) outweigh its costs (C). This will tend to be true the more the market undervalues a stock (the larger D is), or the more likely shareholders will sell their shares in a given period (the larger $P$ is). ${ }^{166}$

This extremely stylized example shows that shareholders ex ante may want management to reduce the fundamental value of their company im order to increase the short-term stock price. The inequality, PD $>$ C, contradicts the received wisdoin that shareholders would want their managers simply to maximize underlying profits. In that vision of the corporate primcipal-agent relationship, shareholders would place blinders on their managers so that managers would not be distracted by the stock price and instead would keep their eyes focused solely on profits.

The failure of strong-form informational efficiency changes this hypothetical agency contract. Shareholders care not only about maximizing the corporate pie, but also about how the residual returns are divided among shareholders. ${ }^{167}$ When the market lacks strong-form informational efficiency, management decisions about corporate speech will affect the division of residual returns, as shareholders who need to sell in the short term will have lower returns when management fails to disclose an undervalued price. Thus, small amounts of informational mefficiency in the stock market can cause shareholders to demand corporate speech that reduces fundamental value. ${ }^{168}$

The inequality also suggests a testable hypothesis that the amount of corporate speech will increase as the probability of liquidity sales increases. Structural characteristics such as the stock's rate of trading turnover or tlie percentage of institutional ownership may be good proxies for this probability. If stockholders "buy and hold," they will

$$
\begin{gathered}
D-C>D-P D \\
-C>-P D, \\
P D>C .
\end{gathered}
$$

166 The inequality compares the marginal expected benefits of disclosure (PD) with its marginal cost (C).

167 The conflict between shareholders in dividing the corporate pie was at the heart of the Transamerica liquidation. See Speed v. Transamerica Corp., 235 F.2d 369 (3d Cir. 1956), modifying 135 F. Supp. 176 (D. Del. 1955); Zahn v. Transamerica Corp., 162 F.2d 36 (3d Cir. 1947), rev'g 63 F. Supp. 243 (D. Del. 1945).

168 This result will hold strictly in this simple model only if the unexpected piece of good news in nondiversifiable. For a larger discussion of how diversified shareholders might demand corporate speech that reduces underlying profits, see infra text accompanying notes 187-90. 
want their managers to spend less time and money talking to the market because there is a lower probability $\mathbf{P}$ that they will sell in any given period. Conversely, shareholders that turnover their stock regularly (high P) will want their managers to spend more money on speaking to the market when the firm is undervalued.

The costs of credible corporate speech go well beyond the direct costs of advertiseinents and financial audits. As Macey and Miller argue, one cost of early disclosure may be an impaired ability to exploit corporate opportunities such as the opportunity to buy surrounding land on the cheap after a successful Texas Gulf-like drilling. ${ }^{169}$ Moreover, the leading explanations for a host of financial decisions-including dividend policy and the issuance of debt and securities-turn on "sigualing" theories under which the managers' financial decisions sigual to the market the imderlying value of the corporation. ${ }^{170}$ Stock sphits, for example, may sigual a coinpany's expectation of higher dividends: This is consistent not ouly with the empirical findings that stock prices increase when stock splits are announced, ${ }^{171}$ but also with the finding that when coinpamies fail to increase their dividends after a stock split, their stock prices fall to levels prevailing well before the split. ${ }^{172}$

These einpirical findings suggest that companies face a trade-off between communicating with a stock split the prospect of higli future dividends today or waiting for information about the value of future dividends to be revealed at a later point in time. For high-value firms, this parallels the trade-off in the preceding nodel: weighing the costs

169 Macey \& Miller, supra note 8, at 1071.

170 See, e.g., Bliattacharya, Imperfect Information, Dividend Policy, and "The Bird in the Hand" Fallacy, 10 Bell J. Econ. 259 (1979); Gilson \& Kraakman, supra note 96, at 603; Gonedes, Corporate Signaling, External Accounting, and Capital Market Equilibrium: Evidence on Dividends, Income, and Extraordinary Items, 16 J. Acct. Res. 26, 30 (1978); Leland \& Pyle, Informational Asymmetries, Fimancial Structure, and Financial Intermediation, 32 J. Fin. 371 (1977); Myers \& Majluf, Corporate Financing and Investinent Decisions When Firms Have Information that Investors Do Not Have, $13 \mathrm{~J}$. Fin. Econ. 187 (1984); Ross, The Determinants of Financial Structure: The Incentive-Signalling Approacl, 8 Bell J. Econ. 23 (1977); Watts, The Information Content of Dividends, 46 J. Bus. 191 (1973).

In game-theoretical terms, a financial policy can represent a credible signal of high firm value, if it is cheaper for high-value firms to undertake that policy. E. Rasmusen, Games and Information: An Introduction to Game Theory 206 (1989); see Ayres, supra note 18; Ayres, Playing Games witl the Law, 42 Stan. L. Rev. 1291 (1990).

171 Fama, Fislier, Jensen \& Roll, The Adjustment of Stock Prices to New Information, 10 Int'1 Econ. Rev. 1 (1969).

172 Id. at 16-17. 
of communication versus the benefits of a higher current stock price. ${ }^{173}$ The primary imphication of growing signaling literature for this discussion is that the costs of communicating information about fundamental value are not insignificant. ${ }^{174}$ As a result, when markets lack strong-form informational efficiency, managers' objectives diverge significantly from simple maximization of underlying profits.

\section{Negative Inferences About Expected Events}

The simplifying assuniptions of the trade-off model can be complicated in several ways. In the initial example, the good news was unexpected, so that the market could not draw inferences from the corporation's failure to speak. In other contexts, lowever, the market will expect management to have nonpubhic information (about, for example, the continued development of announced research). In such situations, the market may draw negative inferences from management's failure to speak. The market would reason that the corporation would, by the inequality PD $>\mathrm{C}$, speak only if the stock were sufficiently undervalued-so silence connotes an mcreased probability that the firm is overvalued. The market would discount accordingly its assessment of the stock's value. ${ }^{175}$

This analysis suggests that larger market discounts will correspond to the larger probability of hiquidity selling. Because shareholders witl a high probability of hquidity selling will want their managers to speak about even smaller amounts of undervaluation, the market will realize that there is an even larger probability that the stock is overvalued. ${ }^{176}$ If the market severely discounts share price in response to

173 By contrast, for low-value firms the false signal of a stock split raises current price above fundamental value but lowers future value (possibly below pre-sphit level). The temptation to send a false signal will be especially great when the low-value firm has shareholders with a high probability of selling during the interim period. This suggests a testable hypothesis that stock sphits will send stronger signals when the sphitting corporation has low-turnover shareholders, because these shareholders will be less likely to send false signals. Similar "turnover" hypotheses could be constructed for other financial policies, such as issuing stock or paying dividends, that signal information about a firm's underlying profits.

174 See, e.g., R. Brealey \& S. Myers, supra note 64, at 294 ("A stock sphit seems an expensive way to send the inessage.").

175 For a similar argument regarding additional stock issues, see Myers \& Majluf, supra note 170 , at 188 .

176 For example, if the corporation has a small stock turnover (which implies a low probability (P) of sale in any given period), then, by the inequality $P D>C$, the corporation seldoin will speak about the stock's undervaluation. In this situation, silence will not cause a 
this form of selective silence, shareholders may find it advantageous to precommit to silence in certain specified situations, even when the stock is significantly undervalued.

\section{Heterogeneous Shareholders}

The stylized trade-off inodel also assumed that shareholders were homogeneous. Relaxing this assumption, however, may create an even greater deinand for corporate speech that has a nonfundamental objective. For example, the inside information to which managers are privy in the initial period may not become known to the entire market simultaneously. Market specialists may play a role akin to palace guards who are situated to learn about inner workings of a corporation before the general market. ${ }^{177}$ In terms of our earher formulation, ${ }^{178}$ it may be that if managers do not speak in the imitial period, these palace guards will learn about news in the second period, and that the general inarket will ouly acquire the information costlessly in the third period. Under these assumptions, the probability $(P)$ that shareholders sell in a given period may not be exogenous to the model: when the palace guards hear the news in the second period, they will start to buy the underpriced stock. Palace-guard purchases will bid up the stock's price, ${ }^{179}$ thus increasing the number of shareholders who sell in the second period (before the information is known to the entire market). ${ }^{180}$

significant stock price discount, because the management will fail to speak about all but the most significant pieces of good news. The failure to speak about good news counterbalances much of the failure to speak about bad news. In other words, when $P$ is low, management censors almost all of the information, so the market cannot draw negative inferences from silence. In contrast, when $\mathbf{P}$ is high, management will censor only the bad news, and the market will assume that no news is bad news. See Akerlof, The Market for "Lemons": Quality Uncertainty and the Market Mechanism, 84 Q.J. Econ. 488 (1970).

177 See Haddock \& Macey, Regulation on Demand: A Private Interest Model, with an Application to Insider Trading Regulation, 30 J.L. \& Econ. 311, 314-19 (1987).

178 See supra text accompanying notes 159-63.

179 See Grossman \& Stightz, supra note 113, at 393; Stout, supra note 99, at 1278.

180 The term "palace guards" suggests, however, that the market specialists may perform a valuable function in return for their profits from proximity. See Gilson \& Kraakman, supra note 96, at 569-79; Grossman \& Stiglitz, supra note 113 .

The palace-guard effect also provides one of the strongest arguments for allowing corporations contractually to sanction insider trading. Although insider trading may represent a windfall profit to the insider, from the standpoint of social efficiency the only result worse than a windfall to insiders would be the wasting of real resources by palace guards to discover information that insiders could transmit more cheaply to the market. Nevertheless, the palace- 
This palace-guard effect would increase dramatically shareholders' deinand for corporate speech because shareholders would seek assurance that palace guards would not receive a disproportionate amount of the gams from correcting the price of undervalued stock. Shareholders may demand expenditure of resources (C) on corporate speech in the first period, not only because it distributes the information more quickly, but because it distributes the information more uniformly than the alternative process by which news leaks to the market.

The inajor result of this Section has been that when stock markets are not fundamentally and informationally efficient, shareholders may want their managers to pursue objectives other than merely inaximizing underlying profits. Yet, in moving away from profit maximization as the unitary objective of management, we interject the possibility of disparate objectives for different shareholders. Shareholders of corporations with palace guards having earher access to fundamental information are likely to deinand more corporate speech, as are shareholders who are likely to sell their stock for liquidity reasons.

If different types of shareholders hold a given corporate stock, whose objectives should management pursue? The Tiebout model of local government offers the classic economic solution to this problem. ${ }^{181}$ Under this theory, corporations should, at their inception, announce their planned quantity and quality of corporate speech,

guard effect does not compel the conclusion that shareholders would want to allow insider trading. When the ex ante effects of insider trading on management behavior are sinall, shareholders may be able more effectively to disempower the palace guard by increasing the amount of direct corporate speech.

Dirks v. SEC, 463 U.S. 646 (1983) considered the issue of whether management has an effective option of speaking directly to the market. The Dirks opinion sanctioned the use of insider trading precisely when the Court found that efforts to speak directly to the market had been unavailing. Id. at 662-67. Consistent with the palace-guard theory, the Supreme Court allowed insider trading to displace the profit-taking of the palace guard when direct corporate speech could not accomphish this same end.

Lucian Bebehuk and Chaim Fershtman have analyzed formally the effects of insider trading in a series of working papers. Sec L. Bebchuk \& C. Fershtman, The Effects of Insider Trading on Insiders' Choice Among Risky Investment Projects, Harvard Program in Law and Econ., No. 75 (Sept. 1990); L. Bebehuk \& C. Fershtman, The Effect of Insider Trading on Insiders' Reaction to Opportunities to "Waste" Corporate Value, Harvard Program in Law and Econ., No. 76 (Sept. 1990).

181 Tiebout, A Pure Theory of Local Expenditures, 64 J. Pol. Econ. 416 (1956); see also Amar, Philadelphia Revisited: Amending the Constitution Outside Article V, 55 U. Chi. L. Rev. 1043, 1086 n.152 (1988) (applying Tiebout model to corporate context). 
then allow shareholders to sort themselves by voting with their feet-investing in those corporations that provide their preferred package of speech and divestimg their holdings im corporations that do not. Yet, if heterogeneity persists after shareholders have sorted themselves, ${ }^{182}$ this Section illustrates that inanagers will have difficulty being faithful to masters who have differing objectives. Market inefficiency consequently will change the default objectives of management in ways that turn on the preferences of the underlying shareholders. It will be especially difficult for courts to fill the gaps in the corporate contract when shareholders have different preferences. At a theoretical level, it is difficult to decide how "tailored" the judicial "off-the-rack" rules should be and whether they should change as the ownership of underlymg shares changes. ${ }^{183}$

Irving Fisher and James Tobin both provided "separation" theorems that drastically simplify the lives of corporate managers in these situations. ${ }^{184}$ In a nutshell, these theories suggest that managers need not take into account the risk and diversification preferences of their shareholders because shareholders themselves can obtain these preferences through individual borrowing and investment decisions. ${ }^{185}$ Under the separation theorems, manageinent need only maximize the underlymg profits of the corporation. ${ }^{186}$ This Section has argued that when securities markets are not efficient in the strongest sense of the word, these separation theorems fail and shareholders demand nonfundamental behavior from their inanagers, particularly regardimg corporate speech. It may be, however, that diversified shareholders

182 Different types of shareholders may fail to separate themselves into the preferred corporate contracts for a number of reasons. See Ayres \& Gertner, supra note 15, at 113. Complete separation in the Tiebout model, for example, depends on the existence of a sufficient number of corporate speech investments, which may not exist in equilibrium.

183 As a practical matter, many of the speech decisions (including financial signaling) of corporate management are governed by the busmess judgment rule that, as currently interpreted, will sustain virtually any corporate speech policies. See $R$. Clark, supra note 4 , at 123.

Lewis v. Benedict Coal Corp., 361 U.S. 459 (1960), addressed the broader theoretical issue of whether default rules should be tailored to characteristics of the particular parties. In Lewis, the Court held that most promisors would contract for set-off rights against third-party beneficiaries, but that labor contracts differed; accordingly, a different default should apply. Id. at 468-70.

184 See I. Fisher, supra note 30; Tobim, Liquidity Preference as Behavior Toward Risk, 25 Rev. Econ. Stud. 65 (1958).

185 See R. Brealey \& S. Myers, supra note 64, at 161 .

186 See id. at 22. 
will not demand corporate speech when managers have private information imdicating that the firm is undervalued. If some firms fail to disclose good news and others fail to disclose bad news, then a diversified investor engaged in hiquidity selling ${ }^{187}$ would, on average, sell at the correct price. The possibility of diversifying part of the risk of selling at an undervalued price would correspondingly reduce the nonfundamental demand for corporate speech and resurrect the operation of the separation theorems.

The risks created by informational inefficiency, however, are not all completely diversifiable. ${ }^{188}$ In particular, the risk that palace guards-who have aceess to inside information before the general market-will be on the other side of a transaction is not diversifiable. ${ }^{189}$ This mability to diversify palace-guard risks ineans that even diversified shareholders will have an interest in preempting palaceguard trading through expedited revelation of insider information. ${ }^{190}$ Therefore, the presence of palace guards may cause shareholders, diversified and undiversified alike, to demand costly corporate disclosure, even if such disclosure entails a reduction in the firm's underlying profits.

\section{Efficiency Implications for Structuring Corporate Law}

Stock inarket inefficiencies will also affect the content of legal rules governing corporate organization. If inarkets tend to be fundamentally inefficient, lawmakers may decide to use materiality and damage standards to deter speculation and to control deviations of inarket prices from fundamental value. For example, by restricting the definition of "materiality" to cover only fundamental information, lawmakers could reduce the value of nonfundamental information. By allowing misrepresentations about nonfundamental information, a revised materiality standard might be effective in reducing certain forms of speculation. A more fundamental interpretation of material-

187 Absent lump-sum broker commissions, liquidity selling by diversified shareholders would usually imply a pro-rata sale of the entire portfolio of securities.

188 For example, unanticipated news of undervaluation will not be diversifiable because, by virtue of the fact that the news is unanticipated, the market will be unable to discount or inflate the ex ante price to reflect the probability of its occurrence.

189 For a general discussion of diversificatiou and its limits, see R. Brealey \& S. Myers, supra note 64 , at 140 .

190 See supra notes $179-80$. 
ity, however, would conflict with the current judicial definition of materiality, which includes information that "a reasonable shareholder would consider" in making an investment decision: ${ }^{191}$ court decisions like Texas Gulf Sulphur have held that "speculators and chartists of Wall and Bay Streets are also 'reasonable' investors entitled to the same legal protection afforded conservative traders."192

The issue of efficient $10 \mathrm{~b}-5$ damages in a fundamentally inefficient narket is even inore perplexing. Imagine that management misrepresents a fundamental fact that would depress a fundamental stock price by ten dollars, but speculative overreaction causes the market price to drop by thirty dollars. Should shareholders who sold during the pendency of the undiscovered he be awarded ten dollars or thirty dollars? One response would be to attempt to divine the hypothetical contract that the corporation and its shareholders would have estabhished ex ante. ${ }^{193}$ Under this analysis, lawmakers should establish a default rule that allows shareholders to recover for nonfundamental price inovements (thirty dollars). Shareholders would demand fundamental information and would be damaged by not being able to sell at what otherwise would have been the market price (although this firmspecific risk is potentially diversifiable). But, as before, efficiencyminded lawmakers might prefer an immutable rule that limits damages to fundamental value (in this case, ten dollars), if such a rule deters socially inefficient speculation. ${ }^{194}$

191 TSC Indus., Inc. v. Northway, Inc., 426 U.S. 438, 449 (1976). In Basic, the Court extended this definition of materiality to the Rule $10 \mathrm{~b}-5$ context. 485 U.S. at 232 .

192 SEC v. Texas Gulf Sulphur Co., 401 F.2d 833, 849 (2d Cir. 1968) (en banc) (citing H.R. Rep. No. 1383, 73d Cong., 2d Sess., 11 (1934)), cert. denied, 394 U.S. 976 (1969).

193 See supra text accompanying note 30 .

194 For a recent description of the ill effects of excessive speculation, see Lowenstein, supra note 111 .

The same policy concerns are at issue with statutory restrictions on appraisal right remedies for publicly traded corporations. Beginning in 1967, a number of states adopted "stock market" exceptions to appraisal right statutes that made appraisal only available to investors whose shares are not histed on a national exchange. See Stout, supra note 99, at 1286 . If the national exchanges are not fundamentally efficient, lawmakers need to decide whether shareholders are entitled to nonfundamental overvaluation or should be limited to nonfundamental stock price undervaluation. In either case, the hypothetical contract analysis may conflict with efforts to eliminate the externality of speculation. 


\section{CONCLUSION}

This Article has addressed two issues at the heart of Basic Inc. v. Levinson: (1) whether corporate misrepresentation constitutes a breach of management's fiduciary duty to shareholders; and (2) whether the efficiency of the capital markets can replace the traditional requirement of detrimental reliance on the misrepresentation in Rule 10b-5 litigation. In answering the first question, this Article has emphasized the contractual nature of management's agency relationship with shareholders. The fiduciary duty to tell the truth or pay damages is akin to a contractual warranty of honesty. Corporations should be allowed to waive this warranty, but in contracting around this default rule, management should be forced to inforn histeners that the corporate speech is unwarranted, "as is" speech. This Article has argued that market forces will ensure that few firms opt for unwarranted speech, at least as regards hard inforination. To be sure, corporations that warrant their management's speech will encounter significant "no comment" problems, in that the market will draw undesired inferences from managers' silence or "no comment" responses (to questions concerning, as for example in Basic, merger negotiations). Instead of solving the "no comment" problem by lying, corporations have committed, and would contimue to commit, contractually to remaining silent. Indeed, the enabling function of corporate law can be best furthered not by making it easier for corporations to he without consequence, but by making it easier for corporations to precommit to silence.

In answering the second question, this Article has distinguished betwecn inforinational and fundamental efficiency. Markets that are informationally efficient quickly supply certain classes of information to the market. Markets that are fundamentally efficient only demand and react to information relating to a corporation's underlying profits. A central thesis of this Article has been that these two dimensions of market efficiency are theoretically independent-in that security markets can exhibit one type of efficiency with or without exhibiting the other. Black Monday, for example, strongly evidences that the stock market is not fundamentally efficient, but if anything supports a claim of inforinational efficiency. The Basic opmion itself underscores the failure of analysts adequately to distimguish between inforinational and fundamental efficiency. The plurality argues in favor of the fraud-on-the-market doctrine because the market is informationally 
efficient; the dissent argues against the doctrine because fundamental efficiency is unknowable. Regarding Basic, this Article has argued that (1) both factual premises may be true (as Black Monday suggests); (2) semi-strong forn infornnational efficiency is an adequate ground for fraud-on-the-market standing; and (3) the dissent's skepticism concerning fundamental efficiency raises legitimate concerns about calculating plaimtiffs' damages.

Beyond this analysis of Basic, this Article has explored the relationship between stock market efficiency and management's agency relationship with shareholders. In a world where security markets are both inforinationally and fundamentally efficient in the strongest senses, the default fiduciary duties created by corporate law and desired by shareholders would be quite straightforward: managers should maximize the present discounted value of the firm profits. The leading corporate finance text puts this especially bluntly: "Managers do not need to know anything about the personal tastes of their shareholders and should not consult their own tastes. Their task is to maximize net present value." 195

Either type of capital market inefficiency, however, will change both the fiduciary duties desired by shareholders and the structure of efficient corporate law. A simple model has shown that even a failure of strong-forn inforinational efficiency can lead shareholders to tradeoff underlying profits for a more accurate short-term stock pricc. Essentially, in markets that are not strong-form informationally efficient, shareholders will want their managers to expend real resources to speak credibly to the market when the firm is undervalued. The costs of corporate speech imclude not only traditional expenses of oral and written communication, but the wide range of financial behavior (which imcludes stock splits, dividends, and leverage decisions) that are increasingly thought to "sigual" management's beliefs about the corporation's prospective profitability. Similarly, when security markets are not both fundamentally and inforinationally efficient, management's objective is not merely to maximize underlying value. Sliareliolders may be willing to pay for management speech as a substitute for market efficiency. Moreover, this new corporate objective will turn on the underlying tastes and characteristics of the shareholders. Thus, witlout strong-form imfornational and fundamental effi-

195 R. Brealey \& S. Myers, supra note 64, at 22. 
ciency, managers can no longer toil as profit plow-horses with blinders to the level of its stock price and the preferences of their shareholder masters.

The two Parts of this Article suggest that, in regulating corporate speech, lawmakers need to appreciate more fully the implications of contractual precommitment and stock market efficiency. For courts especially, these two insights will merge when filling gaps im the corporate contract because the content of the hypothetical agency relationship will often turn on whether and to what extent the stock inarket is informationally and fundamentally efficient. 
HeinOnline -- 77 Va. L. Rev. 10001991 